OCT 2 บ 1995

\title{
OSTI
}

\section{ANALYSIS OF STEADY-STATE FLOW AND ADVECTIVE TRANSPORT IN THE EASTERN SNAKE RIVER PLAIN AQUIFER SYSTEM, IDAHO}

U.S. GEOLOGICAL SURVEY

Water-Resources Investigations Report 94-4257

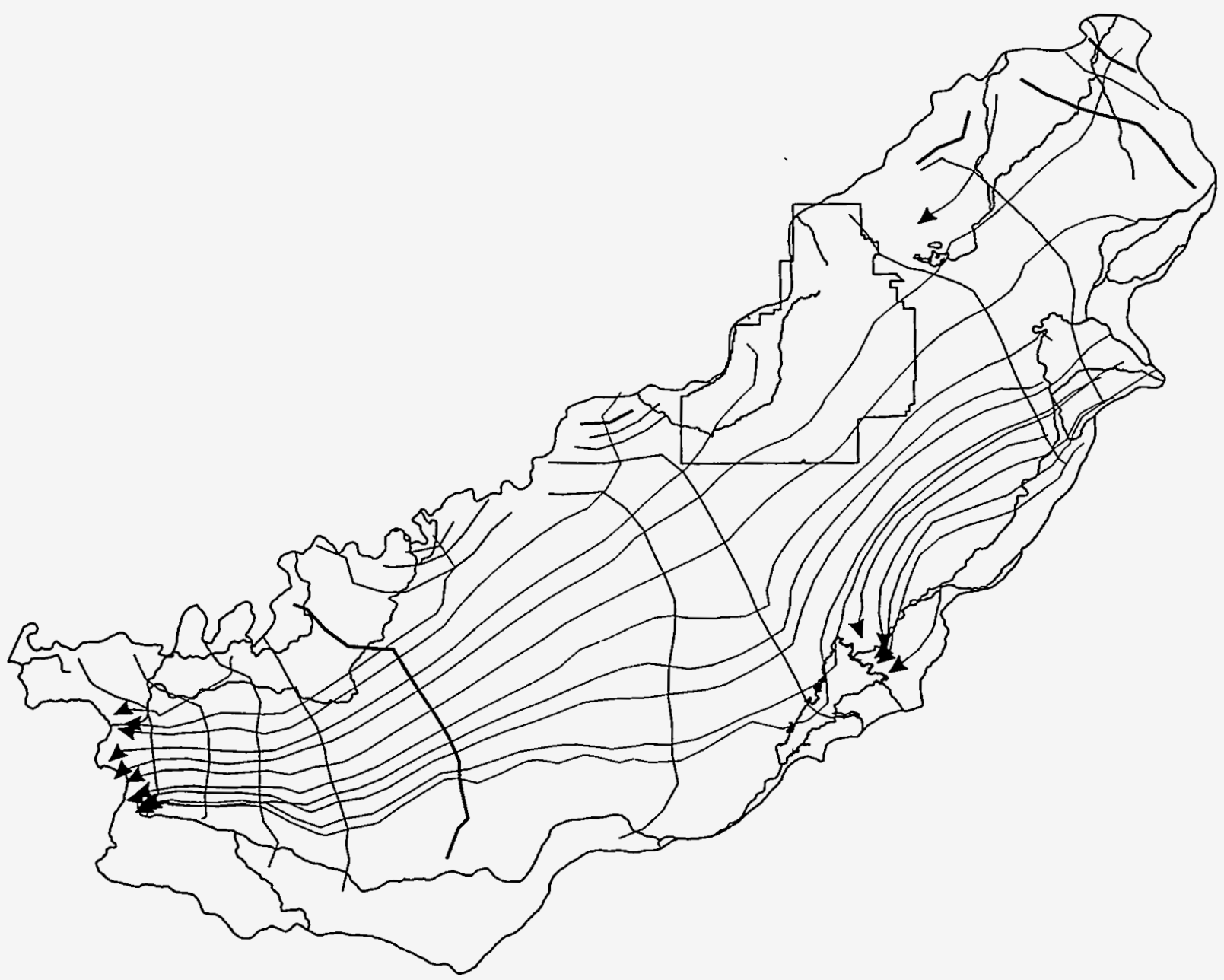


Cover: Graphical representation of the eastern Snake River Plain, Idaho, with ground-water flow lines and potentiometric contours superimposed. Ground-water flow lines are terminated by arrows at discharge locations. 


\title{
Analysis of Steady-State Flow and Advective Transport in the Eastern Snake River Plain Aquifer System, Idaho
}

\author{
By Daniel J. Ackerman
}

\section{U.S. GEOLOGICAL SURVEY \\ Water-Resources Investigations Report 94-4257}

\section{DISCLAIMER}

This report was prepared as an account of work sponsored by an agency of the United States Government. Neither the United States Government nor any agency thereof, nor any of their employees, makes any warranty, express or implied, or assumes any legal liability or responsibility for the accuracy, completeness, or usefulness of any information, apparatus, product, or process disclosed, or represents that its use would not infringe privately owned rights. Reference herein to any specific commercial product, process, or service by trade name, trademark, manufacturer, or otherwise does not necessarily constitute or imply its endorsement, recommendation, or favoring by the United States Government or any agency thereof. The views and opinions of authors expressed herein do not necessarily state or reflect those of the United States Government or any agency thereof.

Idaho Falls, Idaho 


\title{
U.S. DEPARTMENT OF THE INTERIOR BRUCE BABBITT, Secretary
}

\author{
U.S. GEOLOGICAL SURVEY \\ Gordon P. Eaton, Director
}

For additional information write to:

Project Chief

U.S. Geological Survey

INEL, MS 4148

P.O. Box 2230

Idaho Falls, ID 83403
Copies of this report can be purchased from:

U.S. Geological Survey

Earth Science Information Center

Open-File Reports Section

Box 25286, MS 517

Denver Federal Center

Denver, CO 80225 


\section{DISCLAIMER}

Portions of this document may be illegible in electronic image products. Images are produced from the best available original document. 


\section{CONTENTS}

Abstract........................................................... 1

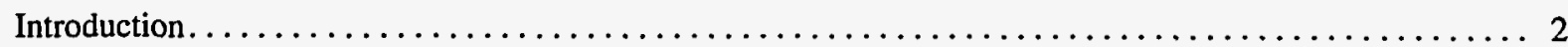

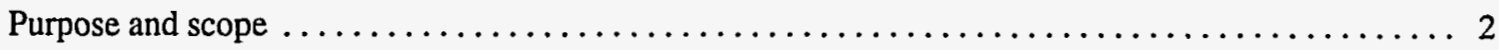

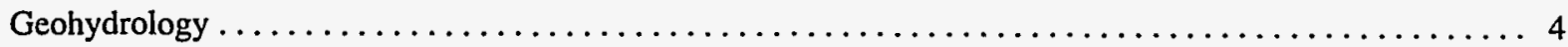

Conceptual models $\ldots \ldots \ldots \ldots \ldots \ldots \ldots \ldots \ldots \ldots \ldots \ldots \ldots \ldots \ldots \ldots \ldots \ldots \ldots \ldots \ldots$

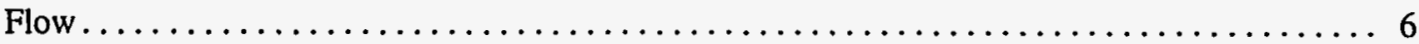

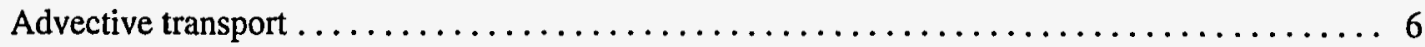

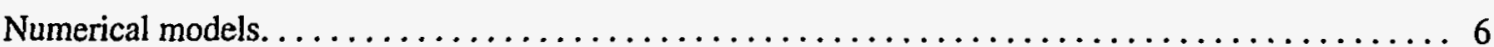

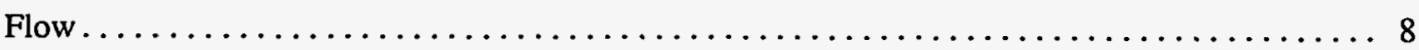

Advective transport $\ldots \ldots \ldots \ldots \ldots \ldots \ldots \ldots \ldots \ldots \ldots \ldots \ldots \ldots \ldots \ldots \ldots \ldots \ldots \ldots$

Model input .................................. 9

Calibration. .................................. 10

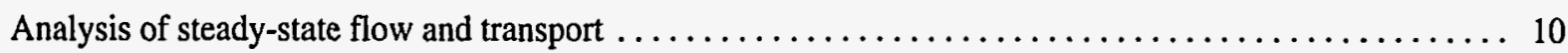

Compartmentalization $\ldots \ldots \ldots \ldots \ldots \ldots \ldots \ldots \ldots \ldots \ldots \ldots \ldots \ldots \ldots \ldots \ldots \ldots$

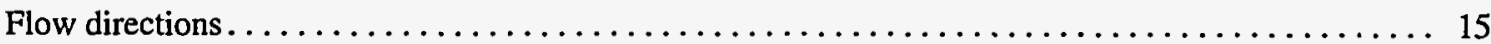

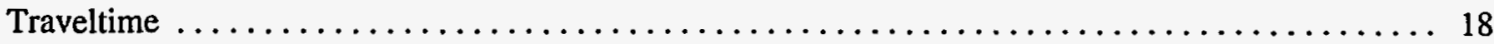

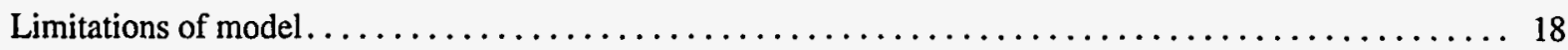

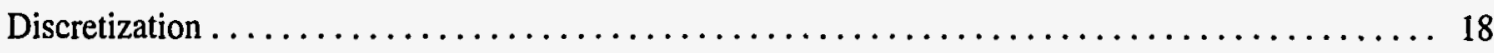

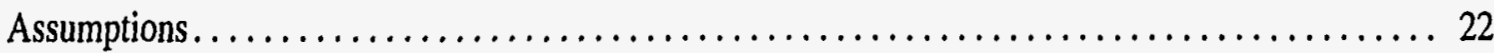

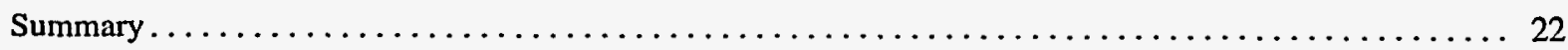

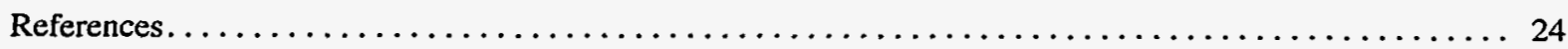

\section{FIGURES}

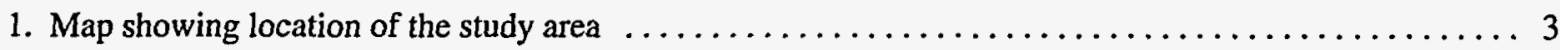

2. Graph showing ground-water budget for the eastern Snake River Plain regional aquifer system, 1980 water year . . . . . . . . . . . . . . . . . . . . . . . . . . . . .

3. Map showing finite-difference grid and boundary of the eastern Snake River Plain regional aquifer

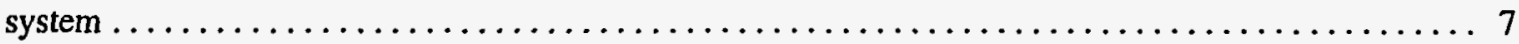

4. Diagram showing simulated flow from well CPP 3 past well USGS $11 \ldots \ldots \ldots \ldots$

5. Graph showing sensitivity of advective traveltime to calibration criteria for porosity $\ldots \ldots \ldots \ldots$

Figures 6-9. Maps showing:

6. Compartments of flow in the eastern Snake River Plain regional aquifer system . . . . . . . . . 14

7. Sensitivity of interpretations regarding fate of flow to assumptions regarding influence

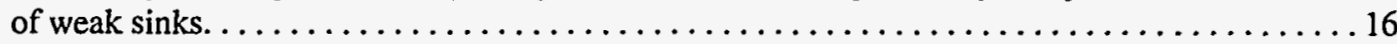

8. Selected pathlines for regional and intermediate flow and configuration of the simulated water table, eastern Snake River Plain regional aquifer system . . . . . . . . . . . . 17

9. Traveltimes for simulated flow originating at the water table in the eastern Snake River Plain regional aquifer system and discharging to the Snake River downstream from Milner Dam . . . . . . . . . . . . . . . . . . . . . . . . . . . 19

10. Graphs showing sensitivity of simulated traveltime to uniform changes in porosity $\ldots \ldots \ldots \ldots$

11. Graphs showing sensitivity of simulated traveltime to influence of weak sinks $\ldots \ldots \ldots \ldots$ 


\section{CONVERSION FACTORS AND VERTICAL DATUM}

\begin{tabular}{rll} 
Multiply & By & To Obtain \\
\hline foot $(\mathrm{ft})$ & 0.3048 & meter \\
mile $(\mathrm{mi})$ & 1.609 & kilometer \\
square mile $\left(\mathrm{mi}^{2}\right)$ & 2.590 & kilometer \\
inch per year & 25.4 & millimeter per year \\
cubic foot per second $\left(\mathrm{ft}^{3} / \mathrm{s}\right)$ & 0.02832 & cubic meter per second \\
picocurie per liter & 0.037 & becquerel per liter \\
\hline
\end{tabular}

Sea level: In this report, "sea level" refers to the National Geodetic Vertical Datum of 1929-a geodetic datum derived from a general adjustment of the first-order level nets of the United States and Canada, formerly called Sea Level Datum of 1929. 


\title{
Analysis of Steady-State Flow and Advective Transport in the Eastern Snake River Plain Aquifer System, Idaho
}

\author{
By Daniel J. Ackerman
}

\begin{abstract}
Quantitative estimates of ground-water flow directions and traveltimes for advective flow were developed for the regional aquifer system of the eastern Snake River Plain, Idaho. The work included: (1) descriptions of compartments in the aquifer that function as intermediate and regional flow systems, (2) descriptions of pathlines for flow originating at or near the water table, and (3) quantitative estimates of traveltimes for advective transport originating at or near the water table.
\end{abstract}

A particle-tracking postprocessing program was used to compute pathlines on the basis of output from an existing threedimensional steady-state flow model. The flow model uses 1980 conditions to approximate average annual conditions for 1950-80.

The advective transport model required additional information about the nature of flow across model boundaries, aquifer thickness, and porosity. Porosity of two types of basalt strata has been reported for more than 1,500 individual cores from test holes, wells, and outcrops near the south side of the Idaho National Engineering Laboratory. The central 80 percent of samples had porosities of 0.08 to 0.25 , the central 50 percent of samples, 0.11 to 0.21 .

Calibration of the model involved choosing a value for porosity that yielded the best solution. Two radiologic contaminants, iodine-129 and tritium, both introduced to the flow system about 40 years ago, are relatively conservative tracers. Iodine-129 was considered to be more useful because of a lower analytical detection limit, longer halflife, and longer flow path. The calibration value for porosity was 0.21 .

Most flow in the aquifer is contained within a regional-scale compartment and follows paths that discharge to the Snake River downstream from Milner Dam. Two intermediate-scale compartments exist along the southeast side of the aquifer and near Mud Lake. One intermediate-scale compartment along the southeast side of the aquifer discharges to the Snake River near American Falls Reservoir and covers an area of nearly 1,000 square miles. This compartment, which receives recharge from an area of intensive surface-water irrigation, is apparently fairly stable. The other intermediate-scale compartment near Mud Lake covers an area of 300 square miles. The stability and size of this compartment are uncertain, but are assumed to be in a state of change.

Traveltimes for advective flow from the water table to discharge points in the regional compartment ranged from 12 to 350 years for 80 percent of the particles; in the intermediatescale flow compartment near American Falls Reservoir, from 7 to 60 years for 80 percent of the particles; and in the intermediate-scale compartment near Mud Lake, from 25 to 100 years for 80 percent of the particles.

Traveltimes are sensitive to porosity and assumptions regarding the importance of the 
strength of internal sinks, which represent ground-water pumpage. A decrease in porosity results in shorter traveltimes but not a uniform decrease in traveltime, because the porosity and thickness is different in each model layer. Most flow was horizontal and occurred in the top 500 feet of the aquifer.

An important limitation of the model is the assumption of steady-state flow. The most recent trend in the flow system has been a decrease in recharge since 1987 because of an extended drought and changes in land use. A decrease in flow through the system will result in longer traveltimes than those predicted for a greater flow. Because the interpretation of the model was limited to flow on a larger scale, and did not consider individual wells or well fields, the interpretations were not seriously limited by the discretization of well discharge.

The interpretations made from this model also were limited by the discretization of the major discharge areas. Near discharge areas, pathlines might not be representative at the resolution of the grid. Most improvement in the estimates of ground-water flow directions and traveltimes for advective flow could be gained by better estimates of recharge from surface-water irrigation.

\section{INTRODUCTION}

The regional aquifer system of the eastern Snake River Plain (hereafter referred to as the aquifer) (fig. 1) is an important component of the hydrologic system in eastern Idaho. The aquifer was thought to be the largest unified ground-water reservoir on the North American continent (Nace, 1958 , p. 136) but is probably second to the Floridian aquifer in the southeastern United States (Heath, 1984, p. 30). Flow in the aquifer is from major recharge areas in the northeastern part of the plain to discharge areas in the southwestern part. About 3,600 $\mathrm{mi}^{2}$, or almost one-third of the eastern Snake River Plain, was irrigated in 1979. Of the irrigated land, about 55 percent was irrigated with surface water, 40 percent with ground water, and 5 percent with surface and ground water
(Garabedian, 1992, p. 6). A comprehensive analysis of the occurrence and movement of water in the aquifer was presented by Garabedian (1992). The analysis included a description of the recharge and discharge, the hydraulic properties, and a numerical model of the aquifer.

To date (1994), no quantitative estimates of ground-water flow directions and traveltimes exist for the aquifer as a whole. Estimates of flow paths and traveltimes are needed to aid in the management and protection of the water resources of the eastern Snake River Plain. Although solute transport has been modeled for a small part of the aquifer (Robertson, 1974; Lewis and Goldstein, 1982) at the Idaho National Engineering Laboratory (fig. 1), an analysis of transport has not been conducted for most of the regional flow system.

The applicability of existing ground-water flow models can be extended with recently developed software and minimal additional information. A model of the aquifer developed by Garabedian (1992) was revisited to address environmental and management problems, better understand the aquifer, and assess needs for future modeling. Hypotheses concerning flow paths, traveltimes, and compartmentalization of the aquifer were tested with the MODPATH advective transport particle-tracking package (Pollock, 1989).

This work is an extension of the work described by Garabedian (1992) and incorporates information he provided on the conceptual model and thickness of the aquifer. Additional information on porosity was needed for the traveltime estimates. The results of this report were compared with field data describing traveltimes for relatively conservative tracers introduced to the flow system and monitored for nearly 40 years.

\section{Purpose and Scope}

The purposes of this report are to: (1) describe compartments in the aquifer that function as intermediate and regional flow systems, (2) describe pathlines for flow originating at or near the water table, and (3) quantify traveltimes for advective transport originating at or near the water table. The model constructed for this study and 


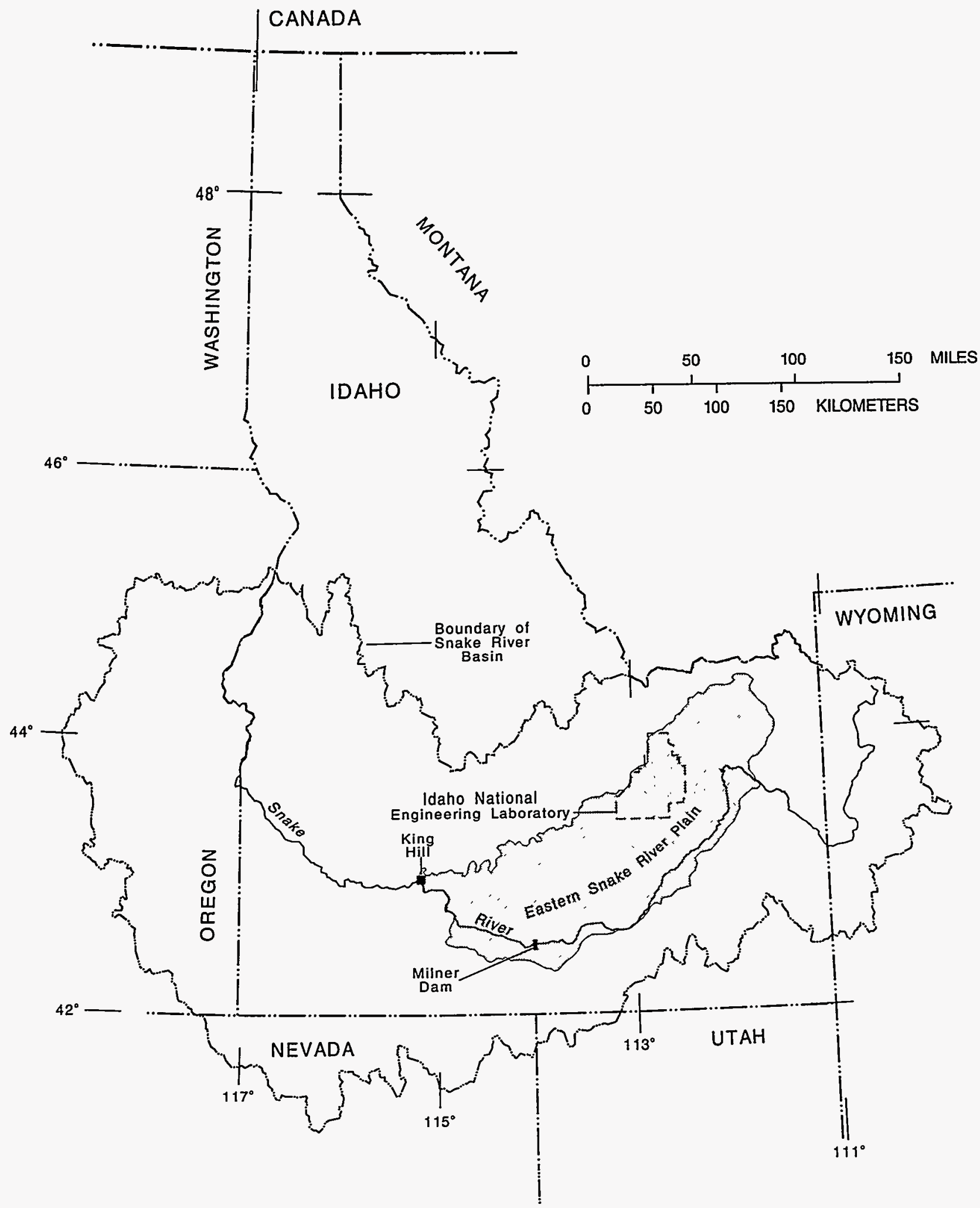

Figure 1. Location of the study area. 
described in this report will aid those concerned with the management and protection of the aquifer. The model will serve as a tool to further our understanding of the aquifer and will aid in assessing the needs for future flow and transport studies of the aquifer.

Because Garabedian's (1992) report is the only published quantitative study of the eastern Snake River Plain and has the only documented numerical model, this study, which uses that model, was limited by the scope, assumptions, and resolution of that report. Specifically, the numerical model of flow used for this report is exactly as presented by Garabedian (1992). Because the MODPATH postprocessing package available for use at the time of this report was limited to steady-state analysis, this report describes the period 1950-80 when flow conditions were relatively stable. Pathlines and traveltimes for advective transport will evolve from those given in the report as the system changes from 1980 conditions.

The study is further restricted to the aquifer that underlies the main part of the eastern Snake River Plain (Kjelstrom, 1992b, p. 49, fig. 39), and to flow at intermediate and regional scales. Specifically, the main part of the eastern Snake River Plain excludes the area south of the Snake River west of 113 degrees longitude. Traveltimes identified in this report consider only advective transport and are generally a conservative estimate of actual transport. No consideration is given to the processes of dispersion or to the physical, chemical, or biological transformation of solutes. For consistency in interpretation, pathlines used for analysis in this report were started within $20 \mathrm{ft}$ of the water table.

\section{GEOHYDROLOGY}

The eastern Snake River Plain is a $10,000-\mathrm{mi}^{2}$ northeast-trending structural basin about $170 \mathrm{mi}$ long and $60 \mathrm{mi}$ wide. The regional aquifer underlying the plain consists of a layered sequence of basaltic-lava flows and cinder beds intercalated with sedimentary deposits, mainly of fluvial and lacustrine origin. Individual basalt flows typically are 20 to $25 \mathrm{ft}$ thick and 50 to $100 \mathrm{mi}^{2}$ in areal extent. The geology and hydrology of the eastern
Snake River Plain aquifer system describe a watertable aquifer of large areal extent.

The hydrology of the eastern Snake River Plain is dominated by the interplay of the Snake River and the regional ground-water system. Recharge to the aquifer is primarily from infiltration of irrigation water diverted from the Snake River and its tributary drainage basins (fig. 2). Almost all ground-water discharge is to springs along the Snake River or to the Snake River. Of 65 springs in the United States that have an average discharge of more than $100 \mathrm{ft}^{3} / \mathrm{s}, 11$ springs or groups of springs are along the Snake River from Milner Dam to King Hill (Meinzer, 1927, p. 42-51).

Changes in water use and management have had a significant effect on the ground- and surfacewater systems. Application of surface water for irrigation increased recharge to and storage in the aquifer (Kjelstrom, 1992b, p. 1). During more than 100 years of irrigation, annual recharge to the aquifer increased by about 70 percent (Lindholm, 1993, p. 2). Storage in the aquifer increased until about 1951, decreased from 1952 to 1964 , and has decreased since 1976 because of increased pumpage of ground water, changes in irrigation practice, and persistent drought (Kjelstrom, 1992b, p. 1). The average ground-water discharge, which is mainly from spring flow, along the north side of the Snake River between Milner Dam and King Hill for the 1993 water year was estimated to be $5,090 \mathrm{ft}^{3} / \mathrm{s}$ (L.C. Kjelstrom, U.S. Geological Survey, written commun. 1994), roughly equivalent to the discharge in 1917 (Kjelstrom, 1992a).

For additional discussions of the geology of the eastern Snake River Plain and the hydrology of the aquifer, the reader is referred to reports by Garabedian (1992), Whitehead (1992) and Lindholm (1993).

\section{Conceptual Models}

The conceptual model of flow in the aquifer and details of numerical simulations given by Garabedian (1992, p. 29-50) are summarized here and in the section of this report entitled "Numerical Models". The approach used by Garabedian was to develop a numerical model of the aquifer to refine and extend concepts of regional ground-water 


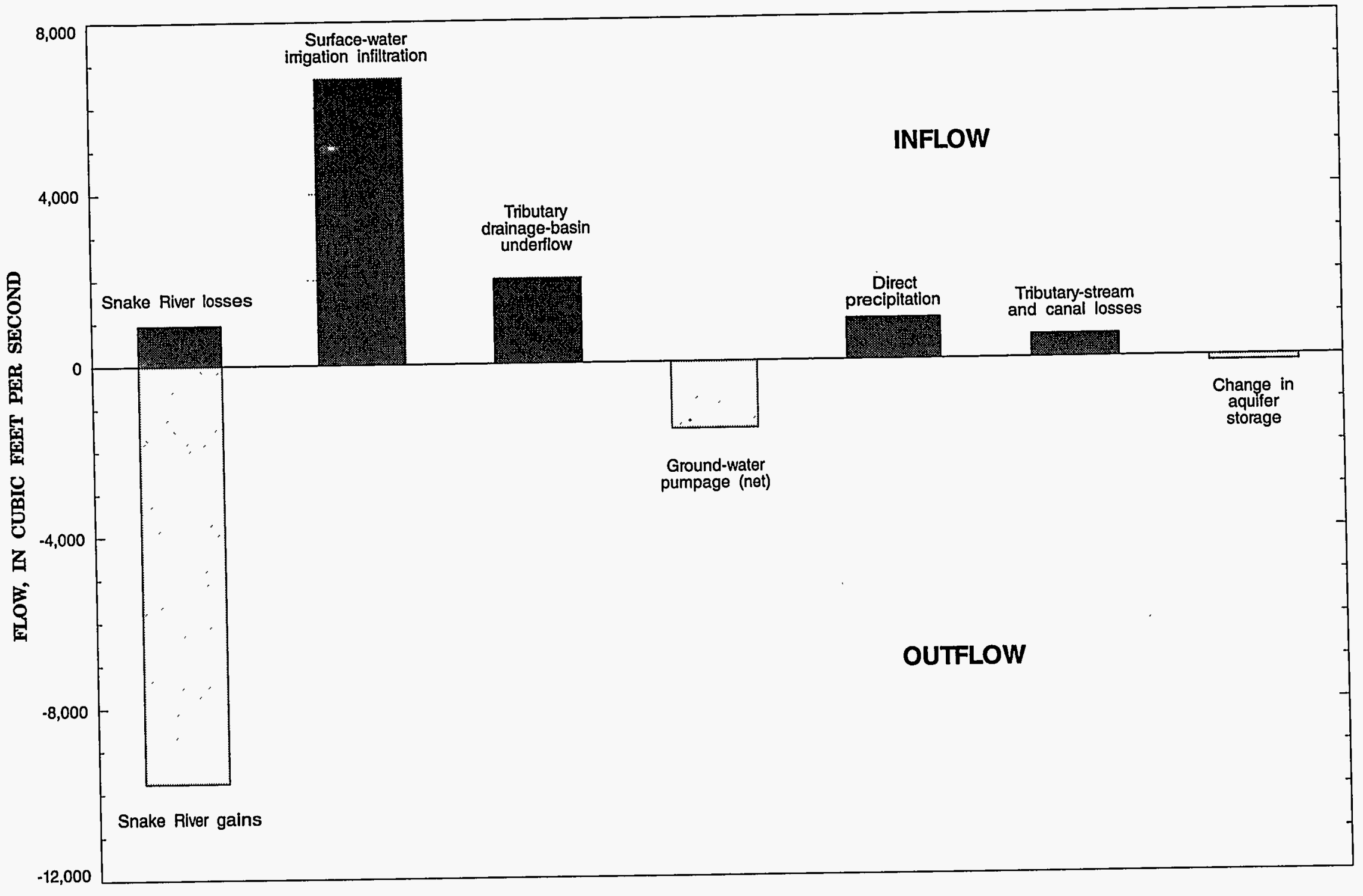

Figure 2. Ground-water budget for the eastem Snake River Plain regional aquifer system, 1980 water year. From Garabedian (1992, table 15) 
flow. After initial conceptualization of the hydroogy, the study progressed in stages from a twodimensional steady-state parameter estimation model to three-dimensional steady-state and transient models. Estimates of recharge developed in the study, estimates and measurements of discharge, and water-level measurements in more than 800 wells were used to calibrate the transmissivity distribution, aquifer leakance, conductance of riverbeds and spring outlets, and storage coefficient. For each stage of the model development and calibration the results of simulation were compared with the knowledge of the aquifer. The final stage in model development was to document the sensitivity of model response to changes in transmissivity, storage, leakance, recharge, riverbed or spring-outlet conductance, groundwater pumpage, and tributary drainage-basin underflow.

\section{Flow}

The direction of ground-water flow in the aquifer is generally from the northeast to the southwest, from areas of recharge to areas of discharge (Garabedian, 1992, p. 21). On a regional scale, ground water moves horizontally thorough interflow zones, cinder beds, and fractures in basalt. For most of the aquifer, flow is virtually two-dimensional (Garabedian, 1992, p. 61). Large vertical head gradients exist in major discharge or recharge areas and along the margins of the flow system. Most recharge is from infiltration of surface water diverted for irrigation and leakage from the Snake River and its tributaries. Underflow from tributary basins and, to a lesser degree, precipitation, also recharge the aquifer. Aquifer discharge is largely spring flow to the Snake River and water pumped for irrigation. Major springs are along the Snake River from Milner Dam to King Hill (river reaches 1 to 4) (fig. 3) and immediately north and east of American Falls Reservoir (river reach 7). A ground-water budget for the 1980 water year (fig. 2) shows the magnitude of individual categories of inflow and outlfow.

Hydrologic conditions in the aquifer were stable for the period $1950-80$ relative to the period 1880-1950. Garabedian (1992, p. 31) assumed that 1980 conditions approximated average annual conditions for 1950-80 and represented a steadystate condition. The aquifer was nearly at steady state in 1980 with fluxes nearly equal to the average flux for the period 1950-80. The change in storage $\left(138 \mathrm{ft}^{3} / \mathrm{s}\right)$, calculated from water-level changes in the aquifer, was only slightly smaller than the residual in the budget $\left(220 \mathrm{ft}^{3} / \mathrm{s}\right)$ that Garabedian (1992, table 15) compiled for the ground-water system.

\section{Advective Transport}

Quantitative estimates of transport require information on the average linear ground-water velocity. Specifically, additional information is needed about the nature of flow across model boundaries, aquifer thickness, and porosity. All flow into or out of the aquifer, except well discharge, was assumed to occur as flow across the boundary of the aquifer. Well discharge was considered to be distributed throughout a given aquifer block as discretized for this analysis. The thickness of the aquifer in the conceptual model for advective transport follows that used in the flow model (Garabedian, 1992, p. 38, fig. 23, pl. 5). The porosity of the aquifer was considered to be the effective porosity of the dominant rock type, basalt.

Regional flow in the aquifer is, in some places, intercepted by large-capacity wells. Except in the case of local contamination, most individual wells probably do not remove an appreciable amount of any contaminant moving through the aquifer. The conceptual model of advective transport did not consider the effects of wells or well fields (weak sinks) that do not capture a large part of regional flow.

Because the model of flow approximates average annual conditions for $1950-80$ with the conditions in 1980, advective transport also approximates average annual movement for 1950-80.

\section{NUMERICAL MODELS}

Two numerical models were used to simulate steady-state advective transport in the aquifer. An existing model simulates three-dimensional 


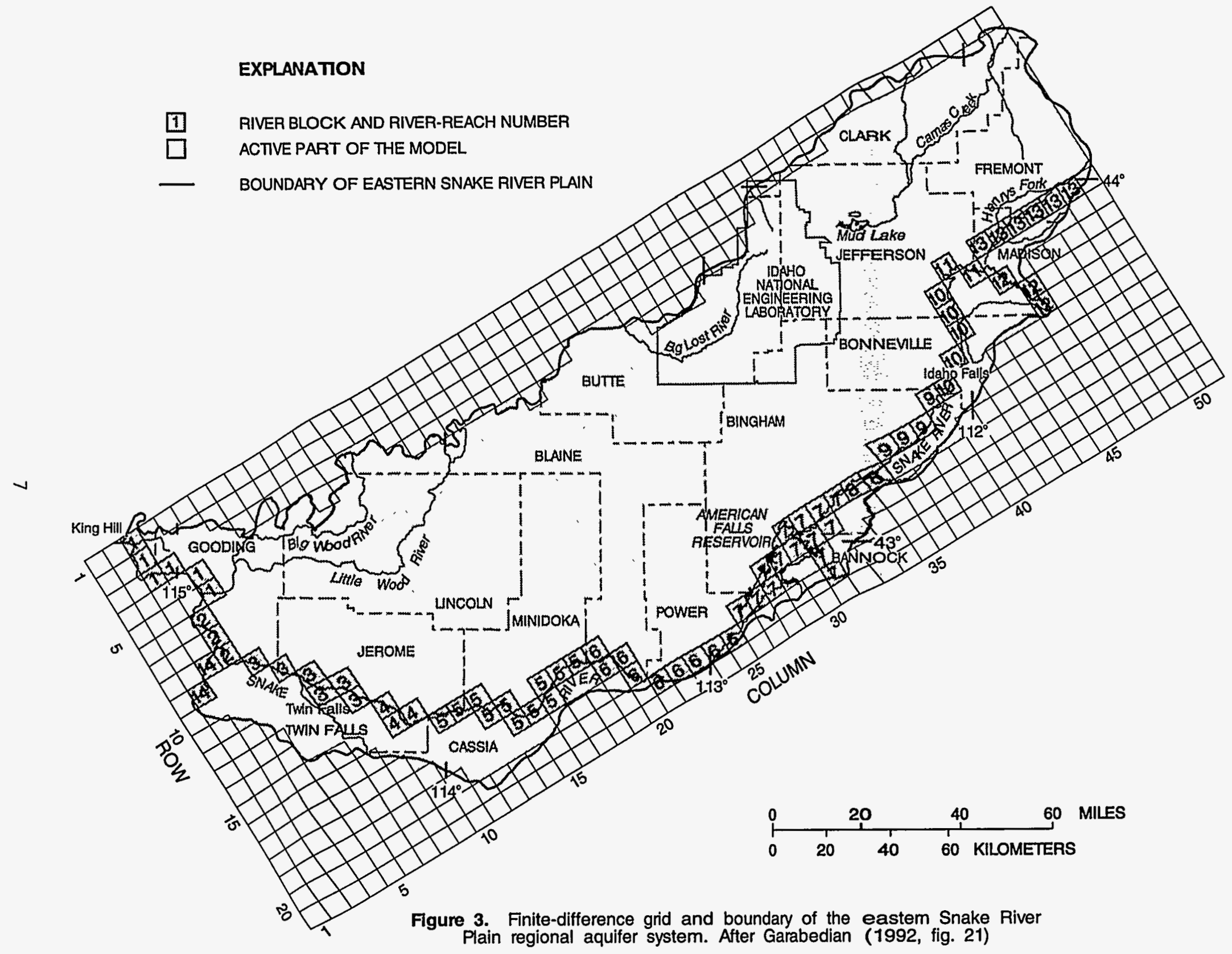


steady-state flow, and an advective transport model developed as part of this study computes threedimensional pathlines. The numerical models of flow and advective transport used in this study were developed from the conceptual models and solved using computer model codes (McDonald and Harbaugh, 1988; Pollock, 1989), which are in the public domain. For further information please see the cited reference to the model code or software. Data sets for the models used in this report are available from the U.S. Geological Survey, District Office, Boise.

Three results were obtained from numerical simulations of advective transport: endpoints of flow, direction of movement, and traveltime. Model evaluation consisted of two parts, calibration and sensitivity testing. Calibration of the transport model involved choosing a value for the least known or defined parameter, porosity, that yielded the best solution. The best solution was judged to be that which best simulated the observed traveltime of the most conservative tracer. Sensitivity testing followed the calibration and involved documenting the sensitivity of the results to variations in assumptions regarding the strength of internal sinks and porosity or thickness.

\section{Flow}

The model code and input data sets for the flow model were the same as those used by Garabedian (1992). The model used simulated steady-state flow for 1950-80 with four layers and constant transmissivity. Boundary conditions were simulated as specified flux and head-dependent flux using the recharge, well, and river packages and as no flow. Garabedian (1992, p. 31) included small changes in storage as part of the recharge term in the steady-state model calibration. For the flow model used in this report, change in storage was not included. The input data for recharge were those used by Garabedian (1992, p. 60, table 24) for the simulation of hypothetical continuation of 1980 conditions. The transmissivity distribution used in the model of the aquifer was calculated from hydraulic conductivities and thickness of rock types distributed by zones across the aquifer. Isotropic conditions were assumed for horizontal flow because calibration could not be improved with regional horizontal anisotropy. Horizontal hydraulic conductivity decreased with depth as a result of change in character of rock units in the aquifer (Doherty and others, 1979, p. 3; Mann, 1986, p. 21; Garabedian, 1992, p. 10, 42). Hydraulic conductivity values were identical at a given location for layers 1 and 2. Values of hydraulic conductivity for layers 3 and 4 were multiplied by two-thirds and one-third, respectively. Vertical conductance values were calculated assuming vertical to horizontal anisotropies of 0.01 to 0.1 depending on rock type. The discretization of the aquifer used in this study (fig. 3) was identical to that used by Garabedian (1992, p. 38-42, fig. 21). The grid is 21 rows by 51 columns and each cell is $4 \mathrm{mi}$ on a side. Coordinate translation programs given by Newton (1985, p. 5-6) were used to translate from the latitude and longitude of a location to the grid coordinates. The computer code was the version reported in McDonald and Harbaugh (1988) and has had no computational changes from the version used by Garabedian (A.W. Harbaugh, oral commun., 1992).

\section{Advective Transport}

Advective transport in the aquifer was modeled using a particle-tracking postprocessing package, MODPATH and MODPATH-PLOT (Pollock, 1989), developed for use with the USGS modular flow model. The particle tracking postprocessing program was used to compute pathlines on the basis of output from simulations using Garabedian's (1992) three-dimensional groundwater flow model. Because the model used a semianalytical particle-tracking method for steady-state flow, there was no requirement for discrete time steps. The velocity within a block of the discretized aquifer was assumed to change uniformly across the volume, and simple linear interpolation was used to compute the principal velocity vectors within the model cells that represented the flow field. This assumption is a consequence of the method of calculating intercell flow rates in the flow model. Porosity is not necessary for the computations of pathlines of particles but was necessary for the calculation of traveltimes. 
The advection model is a simple means of evaluating the advective transport characteristics of the aquifer (Pollock, 1989, p. 2). The advection model cannot be used to compute solute concentrations in ground water because it does not account for the effect of mixing by dispersion or for the physical, chemical, and biological transformation of solutes. The advection model is a convenient intermediate step between ground-water flow models and advection-dispersion solute transport models.

\section{Model Input}

Aquifer thickness was not an input variable for Garabedian's (1992) work but was used as an intermediate step in the creation of transmissivity arrays for the flow model. Layers 1 and 2 were defined (Garabedian, 1992, p. 38) as the first 200 and $300 \mathrm{ft}$, respectively, of aquifer thickness. Garabedian (1992, pl. 5) presented the distribution of thickness for layers 3 and 4 . These values were transferred to an input array for use in the advective transport model. Layer 3 is $500 \mathrm{ft}$ or less in thickness and is present in the central part of the eastern Snake River Plain. Layer 4 ranges in thickness from 0 to more than $3,000 \mathrm{ft}$ and is present over a slightly smaller area than layer 3 .

The nature of simulated flow across model boundaries is a consequence of the conceptual model of flow and of the software requirements (Pollock, 1989, p. 22-28) for computing the velocity vector field. All flux was distributed evenly across cell faces or as an internal sink. Specified flux modeled using the well package represented pumpage from wells, flow from streams and canals, irrigation-return flow in the Mud Lake area, and underflow from tributary basins. Flux representing inflow from stream and canal losses and from irrigation-return flow was represented as crossing the upper face of the top model cell. Flux representing tributary-basin underflow was apportioned uniformly among vertical cell faces representing the horizontal extent of the aquifer. Specified flux modeled with the recharge package and flux to and from river blocks (head-dependent flux) also were represented as crossing the upper face of the top model cell. Pumpage from wells was represented as an internal sink and was uniformly distributed throughout the volume of a model cell.

Porosity of the aquifer is a calibration variable in the modeling of traveltimes by advective transport. Porosity of two types of basalt strata has been determined for more than 1,500 individual cores from test holes, wells, and outcrops near the south side of the Idaho National Engineering Laboratory (Knutson and others, 1990, 1992). Porosity values were determined for large core samples using volumetric/gravimetric methods (Knutson and others, 1990, p. D-17) and for samples of the core using a helium porosimeter (Knutson and others, 1990, p. D-43). Values from the two methods for several sample sets had correlation coefficients of 0.98 , indicating that effective porosity was very similar to total porosity (C.F. Knutson, EG\&G Idaho, written commun., 1994). The median values of porosity were 0.11 for nonvesicular samples and 0.22 for vesicular samples (Knutson and others, 1992, p. 4-21). A cumulative distribution curve for all samples showed that the central 80 percent of samples had porosities of 0.08 to 0.25 , the central 50 percent of samples, 0.11 to 0.21 (Knutson and others, 1992, fig. 4-10). From the description of more than $3,600 \mathrm{ft}$ of core, Knutson and others (1992, p. 3-8) estimated that approximately 57 percent of the core examined was nonvesicular basalt and 43 percent was vesicular. Bishop (1991) analyzed 71 core samples of a vesicular basalt block taken from a site in the same area as the core samples reported by Knutson and others $(1990,1992)$. The median and mean effective porosities were both 0.23 for the 71 cores analyzed by Bishop (1991, p. 77).

Barraclough and others (1967, p. 61) quoting George H. Chase (U.S. Geological Survey, unpub. data) reported an average porosity of 0.18 for 100 samples of basalt from the Idaho National Engineering Laboratory. Robertson $(1969$, p. 13) also quoting Chase, gave the same value and also gives a value of 0.18 for a single sample of basalt.

Unsubstantiated estimates of porosity used previously are as follows: solute transport modeling for the aquifer at the Idaho National Engineering Laboratory, 0.10 (Robertson, 1974, p.13); solute transport modeling for waste seepage at the Idaho National Engineering Laboratory, 
0.10 (Robertson, 1977, p. $25,31,45$ ); materials balances in the aquifer, 0.06-0.10 (Barraclough and others, 1967, p. 63), 0.07 (Robertson and others, 1974, p. 176); general aquifer descriptions, 0.05-0.15 (Robertson and others, 1974, p. 176), 0.05-0.15 (Barraclough and others, 1967, p. 63).

The choice for a range of probable values for porosity of the aquifer was 0.10 to 0.25 . This range is similar to the range of observed values and was only slightly higher than the range of values used for other studies or suggested by other studies. The presence of interflow zones, clinker beds, and large fractures, which were not present in core samples, would tend to increase the porosity as determined from the analysis of samples.

\section{Calibration}

The two model variables that influenced traveltime calculated from the model output were the porosity and the thickness. Because thickness was an integral part of the flow model, it was not chosen as a calibration variable. Values of porosity used in calibration were constrained by prior information about basalt porosity.

Two radiologic contaminants, iodine- 129 and tritium, both introduced to the flow system about 40 years ago, were available to act as relatively conservative tracers. The half-life for iodine-129 is 15.7 million years and that of tritium is 12.4 years. The contaminants were introduced directly through a 590-ft-deep injection well (CPP 3) at the Idaho Chemical Processing Plant at the Idaho National Engineering Laboratory starting in 1953 (Mann and Cecil, 1990, p. 13). Tritium was first detected in wells at the south boundary of the Idaho National Engineering Laboratory in 1983 (Mann and Cecil, 1990, p. 27). The method detection limit typically used for the analysis of tritium is 500 picocuries per liter. Iodine- 129 was detected in well USGS 11 at a concentration just above background after no more than 38 years (Mann and Beasley, 1994, p. 24). Accelerator mass spectroscopy was used to detect iodine-129 at a concentration of $(1.0 \pm 0.1) \times 10^{-5}$ picocuries per liter in water from well USGS 11 (Mann and Beasley, 1994 , p. 9 , table 2). The traveltime for iodine- 129 was considered to be more useful for comparison with predicted traveltimes because of a lower analytical detection limit, longer half-life, and longer flow path.

The absolute value of the difference between simulated and estimated traveltimes for the radiologic contaminants was chosen as the calibration criterion. A calibration target of \pm 20 percent of the traveltime was set.

An example of how the traveltime for a particle introduced at a location corresponding to the injection well was calculated for various porosities is shown on figure 4 , a projection of the threedimensional path of a particle to the top of layer 1 . The pathline of the particle representing tracer movement did not cross the bottom of layer 1 , a depth of $200 \mathrm{ft}$ below the water table. The calibration value for porosity was 0.21 for iodine-129 and 0.25 for tritium (fig. 5). Values of porosity between 0.17 and 0.25 were within the calibration target for iodine-129. Values of porosity between 0.20 and 0.30 were within the calibration target for tritium. The earliest arrival for tritium is less likely to be detected given the larger method detection limit and the decreased concentration because of radioactive decay. To the nearest two significant figures, the calibration value for porosity was 0.21 ; this value allowed the model to simulate the traveltime for iodine-129 (fig. 5). Values of 0.15 and 0.25 were chosen as representative of the probable range of porosity and were used for sensitivity analysis. Values of porosity yielding traveltimes at the upper end of the range of the tritium calibration targets, 0.25 to 0.30 , were outside the range of probable values for basalt porosity.

\section{ANALYSIS OF STEADY-STATE FLOW AND TRANSPORT}

The results of simulations of particle travel can be analyzed to develop or extend knowledge of the compartmentalization of the aquifer, flow paths in the aquifer, and traveltime for flow in the aquifer. The knowledge of compartmentalization, paths, and traveltimes is valuable for interpretation of studies involving the movement of natural tracers, the movement of contaminants, and the chemical evolution of water in the flow system. 


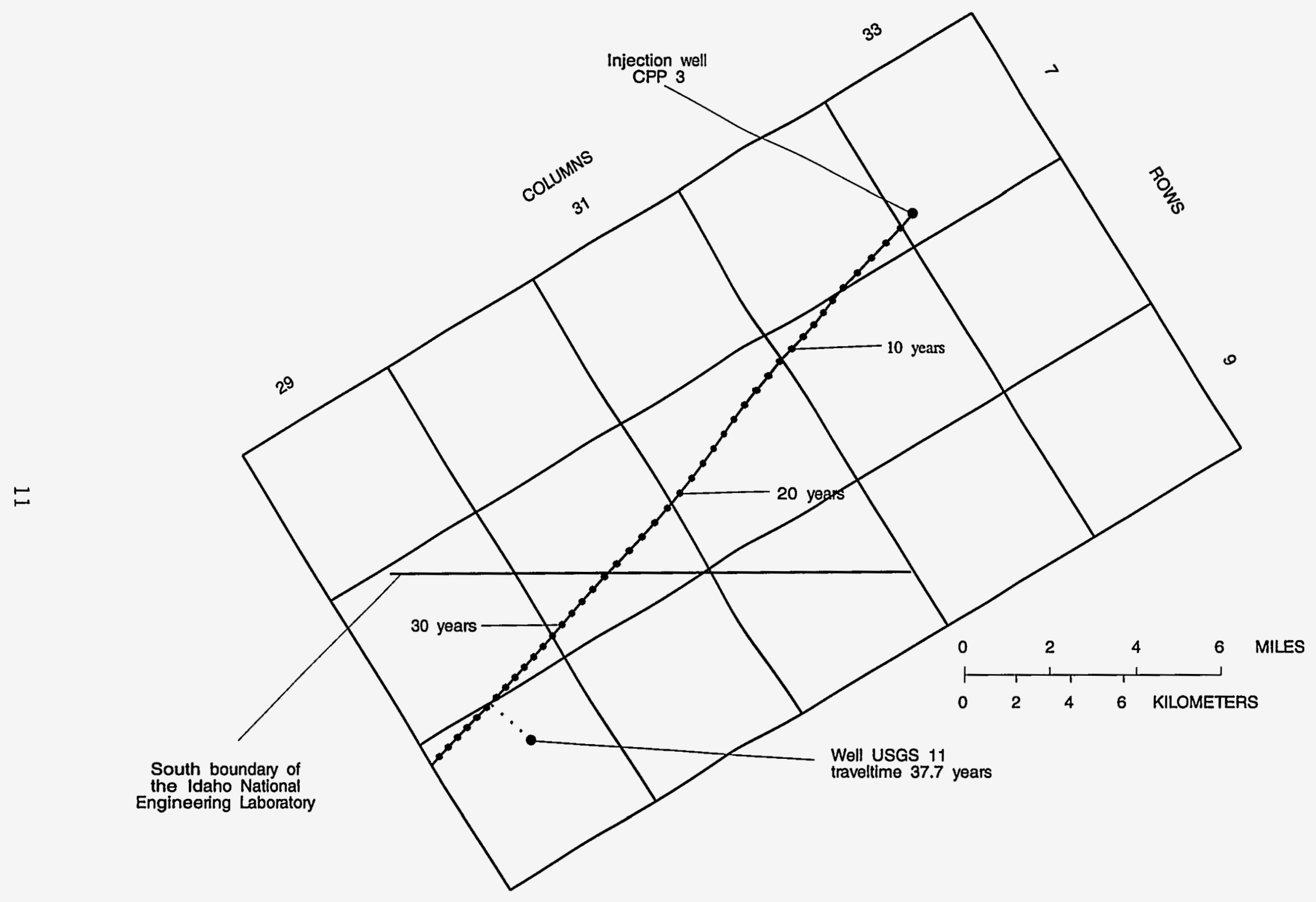

$N$

Figure 4. Simulated flow from well CPP 3 past well USGS 11. [Nodes on pathline are at 1 year intervals. Porosity is 0.21] 


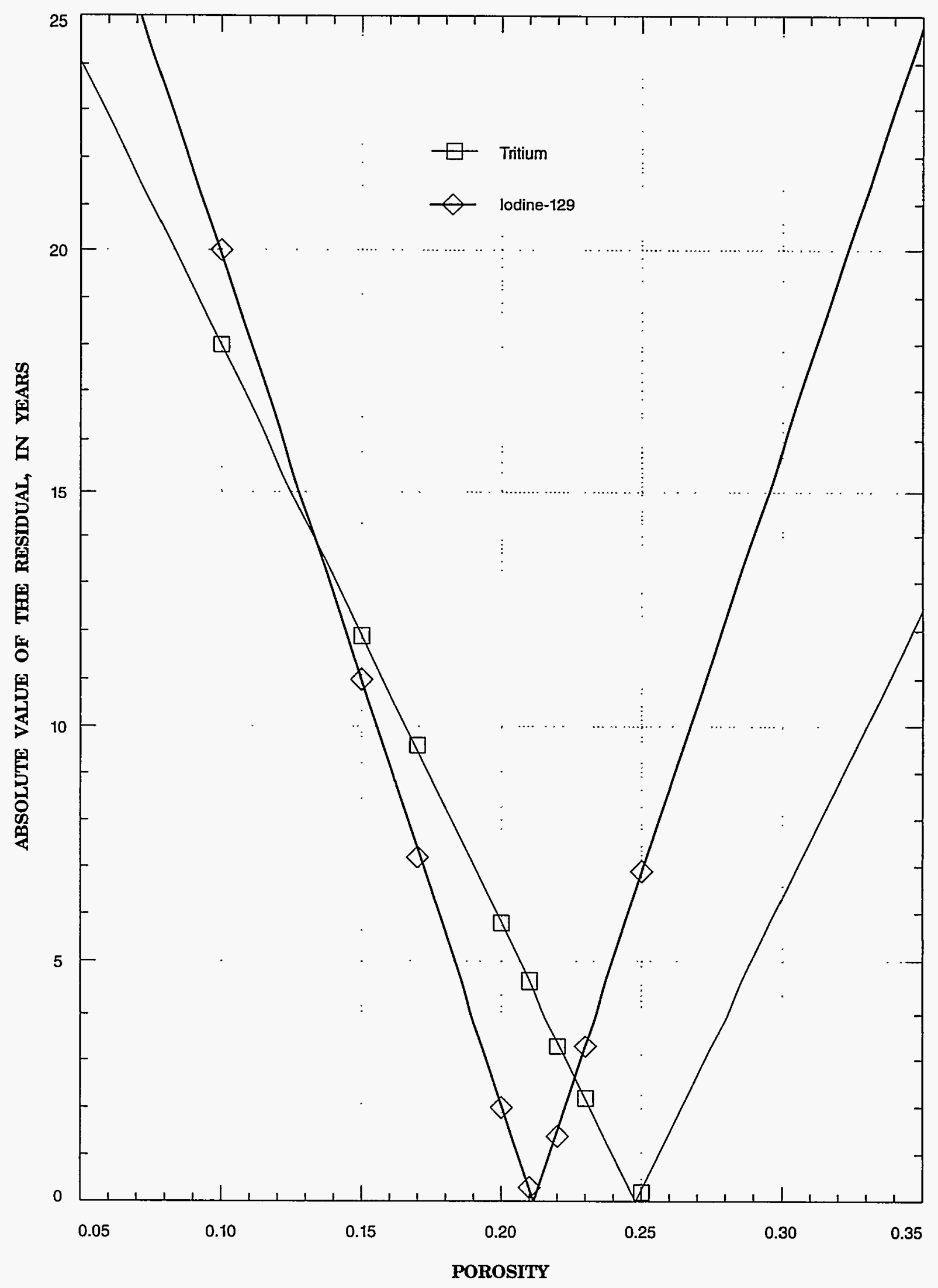

Figure 5. Sensitivity of advective traveltime to calibration criteria for porosity. 
The pathlines represent a calculation that integrates all the knowledge used to construct the flow model, including the location and magnitude of inflow and outflow, the spatial distribution of head and hydraulic parameters, the size and shape of the region of flow, and the equation of flow. In essence, the model is a boundary value problem (Freeze and Cherry, 1979, p. 67). In this model the simulated distribution of head was not directly used to construct the pathlines but was used in the calibration of the transmissivity distribution for the flow model.

\section{Compartmentalization}

An analysis of compartmentalization of the aquifer is illustrated in figure 6. Four particles, equally spaced areally, were started at a depth of 0.9 of the cell height ( $20 \mathrm{ft}$ below the water table) for each cell. The particles were sorted according to the location of the endpoint of flow, and the starting points were posted on a map of the model grid (fig. 6). Most pathlines that didn't end at strong sinks (rivers and springs) in the model river blocks ended in two cells with relatively strong sinks near Mud Lake. Most particles followed pathlines of regional or intermediate scale, although a few were of local scale. The pathlines simulated the movement of a solute introduced to the flow system at or near the water table.

Division of the flow system into intermediateand regional-scale compartments facilitates the discussion of the fate of contaminants that have been or might be introduced to a system. Also, the discussion of the geochemical evolution of waters is usually framed within the concept of a flow system from recharge area to discharge area. The existence of flow paths confined within a compartment has important implications for the fate of contaminants. Generally, a contaminant introduced in a compartment will be discharged within that compartment, limiting the area of concern. But, given that flow is three dimensional, a regional compartment may exist at depth at a given location within the areal projection of an intermediate-scale compartment. This report considers the case where a contaminant is introduced near the water table. The interpretation of compartments of the flow system as simulated by Garabedian's (1992) flow model is qualified by considering the sensitivity of pathline analysis to assumptions regarding the effects of weak sinks.

Most flow in the aquifer is contained within the regional-scale compartment and follows paths that discharge to the Snake River downstream from Milner Dam (reaches 1 to 4). Intermediate-scale compartments exist at two locations along the southeast side of the aquifer and near Mud Lake. The remaining particles, about 1 percent of all particles, follow short paths to river nodes representing the Snake River downstream from American Falls Reservoir (reach 6) or to sinks at the top of the cell and are labeled as miscellaneous local flow.

The American Falls compartment, an intermediate scale compartment along the southeast side of the aquifer, discharges to the Snake River near American Falls Reservoir (reach 7) and covers an area of $1,000 \mathrm{mi}^{2}$ (fig. 6). The American Falls compartment receives recharge from an area of intensive surface-water irrigation. Garabedian (1992, pl. 8) estimated that recharge from surfacewater irrigation and precipitation ranged from 10 to 100 inches per year for most of the compartment. The flow system in the American Falls compartment is apparently fairly stable, because the mean annual ground-water discharge to this reach of the Snake River has been consistent since 1912 (Garabedian, 1992, p. 19).

The Mud Lake compartment, an intermediatescale compartment near Mud Lake, covers an area of $300 \mathrm{mi}^{2}$. Two processes appear to be contributing to the existence of the flow system within the Mud Lake compartment. A band of lower permeability sediments and basalt that underlie an area from northwest of Mud Lake to the Snake River impedes horizontal ground-water movement and contributes to conditions that produce upward flow (Spinazola, 1994, p. 29). Garabedian (1992) and Spinazola (1994) described the distribution of ground-water pumpage, recharge from irrigation, and recharge from stream, lake, and canal losses near Mud Lake. In this area some ground water is pumped or flows from wells to canals and streams for use in areas removed from the ground-water pumpage center. The net result is increased recharge downgradient from the 


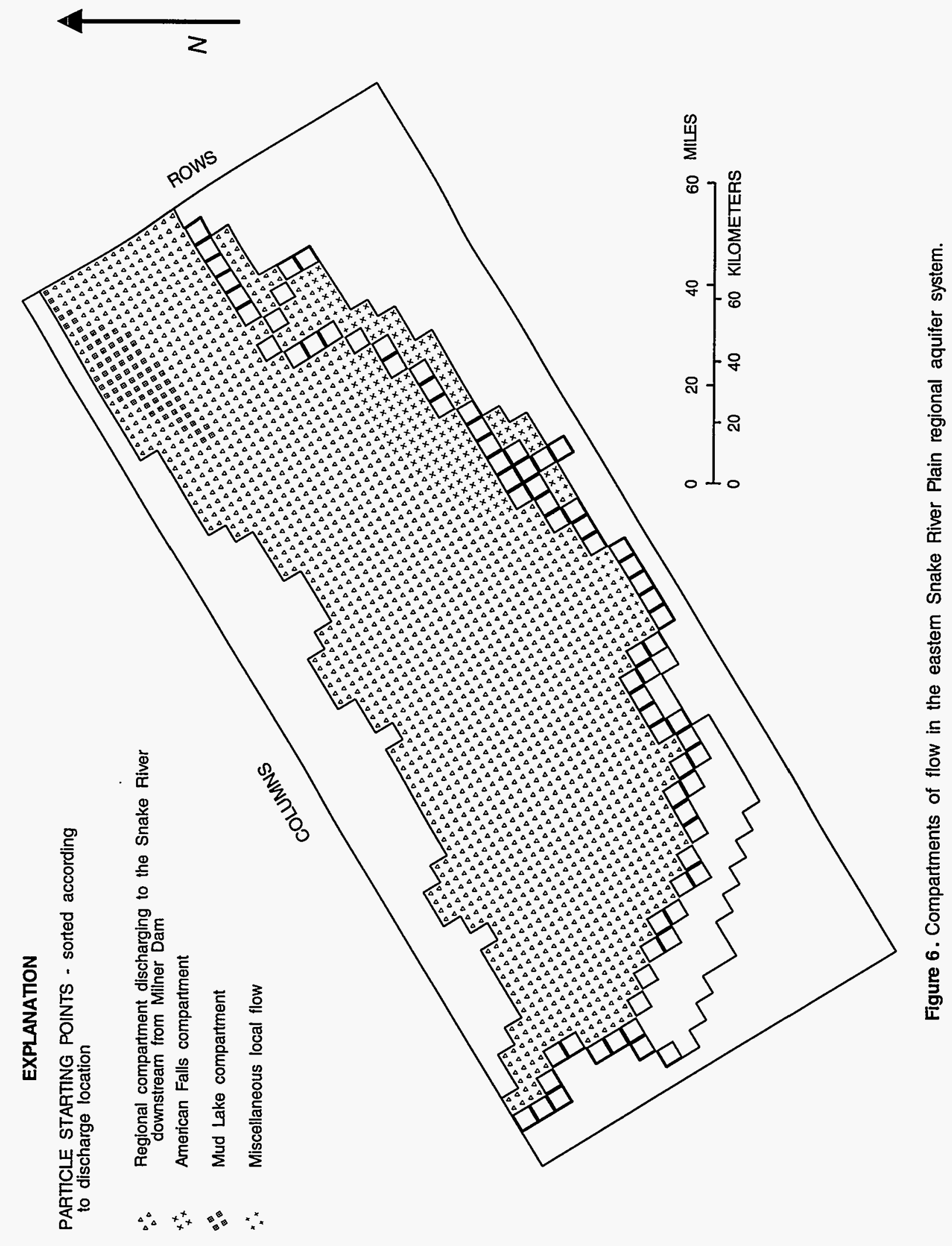


discharge area. The stability or size of the flow system within this compartment is uncertain. Mud Lake has been in existence since before 1900 but increased dramatically in size between 1908 and 1923 (Stearns and others, 1939, p. 95). The existence of Mud Lake before irrigation development may be evidence of a stable discharge area reflecting intermediate-scale flow, but the increase in size is certainly an indication that the compartment is in a state of change.

For the case of a steady-state flow field, the pathlines and end points of particles are not affected by porosity and thickness. End points of flow are sensitive to the assumptions regarding the importance of the strength of internal sinks which, in this model, represent ground-water pumpage. When a model is constructed to represent regional flow, the intricate details of local flow, such as the influence of local wells or local well fields, can not be unambiguously represented. The MODPATH software allows selection of the criteria for terminating pathlines when they reach a cell where discharge to internal sinks is larger than a specified fraction of the total inflow to a cell. To test the sensitivity of model results to the assumption that weak sinks were not important, endpoints of flow and traveltimes were calculated for scenarios where weak sinks of four different strengths were allowed to stop particles. The strengths were fractions greater than $0.8,0.6,0.4$, and 0.2 of the total inflow to a cell. The case where the strength of a weak sink is greater than 0.2 of the total inflow to a cell is the most restrictive, as this represents the case where a smaller internal sink (representing well discharge) would stop particle movement for pathlines that enter that cell in the model. If the ratio of weak sink flux to total flux is 0.2 or greater, then the size of the compartment near Mud Lake is larger, $380 \mathrm{mi}^{2}$, and more miscellaneous local flow is indicated. As illustrated in figure 7, interpretations regarding the compartments of flow are sensitive to assumptions regarding the importance of the strength of internal sinks. The sensitivity of the model to assumptions regarding weak sinks indicates that the size of the Mud Lake compartment might be interpreted as possibly being somewhat larger. If the ratio of weak sink flux to total inflow is 0.8 or greater, then the discharge area increases from one to three cells and the flow system increases to $400 \mathrm{mi}^{2}$. If the ratio is 0.6 or greater (fig. 7), the area increases to $510 \mathrm{mi}^{2}$.

Sensitivity analysis (fig. 7) also indicated the possible existence of a third intermediate- to localscale compartment north of the Snake River upstream from Milner Dam (reach 5). The compartment may constitute an area of $90 \mathrm{mi}^{2}$ and discharge to three cells. This compartment is similar to the Mud Lake compartment in that ground-water usage is substantial and no surfacewater irrigation takes place immediately upgradient (Garabedian, 1992, pls. 8 and 9). Of the areas where ground-water usage is substantial, this area was the first to be developed (Garabedian, 1992, pl. 9).

\section{Flow Directions}

A projection of the pathlines of particles that represent the locations of major inflows to the aquifer is shown on figure 8 . The particles were started at the center of the top face of a cell and at a depth of 0.9 of the cell height. The starting locations corresponded to all cells where inflows were greater than $75 \mathrm{ft}^{3} / \mathrm{s}$ (63 inches per year per cell) and represented 35 percent of the total inflow. The pathlines are a projection to the top layer (water table) of the three-dimensional path. A description of flow paths in a three-dimensional flow system is difficult to construct and portray in two dimensions. The recharge from intensive surface-water irrigation along the southeast side of the aquifer, the American Falls compartment, resulted in a concentration of pathlines. This concentration of pathlines illustrates the increased ground-water flow per unit area in this compartent. Conversely, the relative paucity of pathlines on the northwest side of the aquifer indicates less ground-water flow.

Along the edges of the American Falls compartment, the pathlines for regional flow cross those for intermediate flow. Crossing pathlines depict regional flow passing beneath intermediate flow. At the end of the flow system, the pathlines converge at the discharge area. Because the pathines are an approximation of most flow, pathline density is greatest near cells that represent the river reaches with the greatest gain from the aquifer. 


\section{EXPLANATION}

PARTICLE STARTING POINTS - sorted according

to discharge location

$\therefore \quad$ Regional compartment discharging to the Snake River

downstream from Milner Dam

$x_{+}^{*} \quad$ American Falls compartment

$\Rightarrow \quad$ Mud Lake compartment

$*$ * Miscellaneous local flow

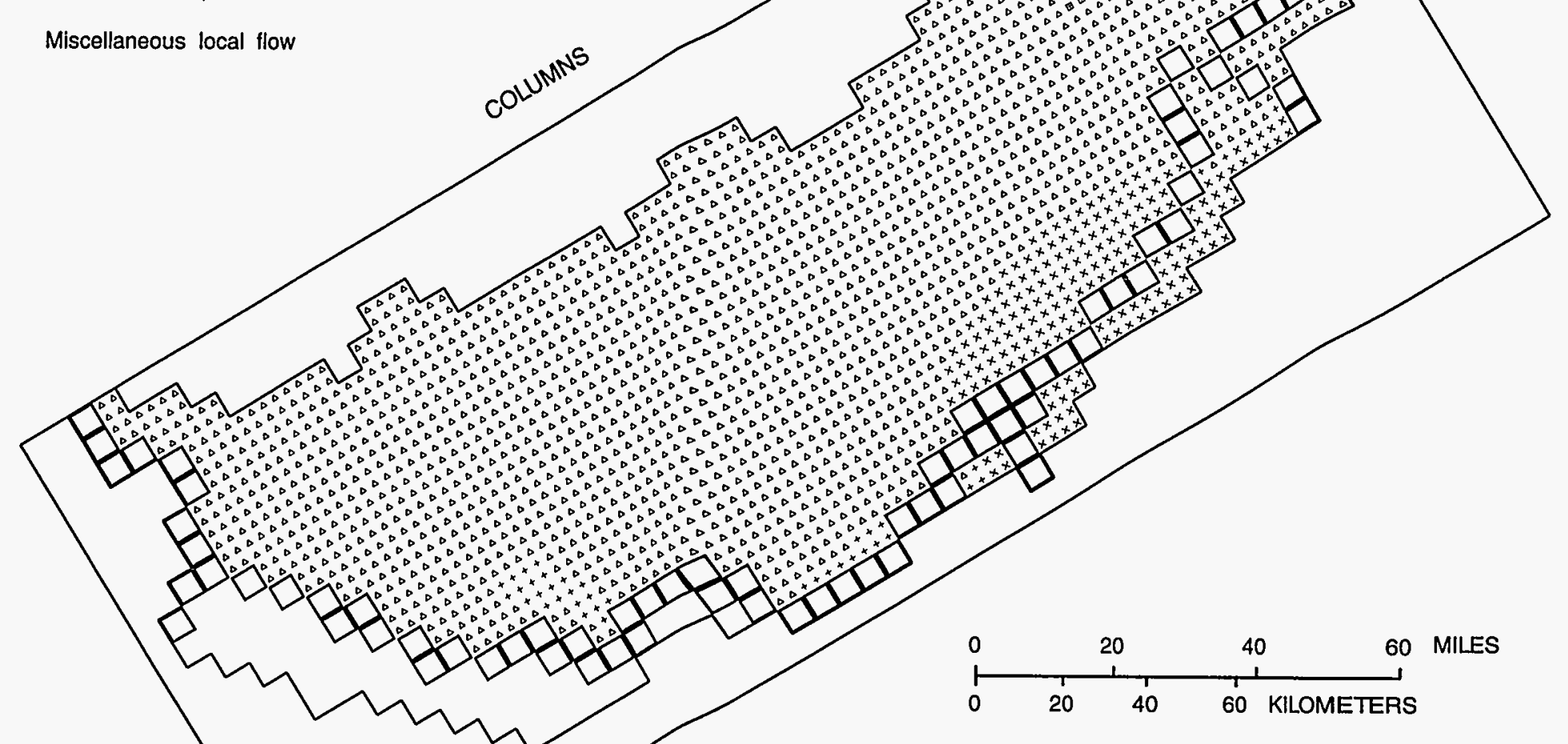

$N$
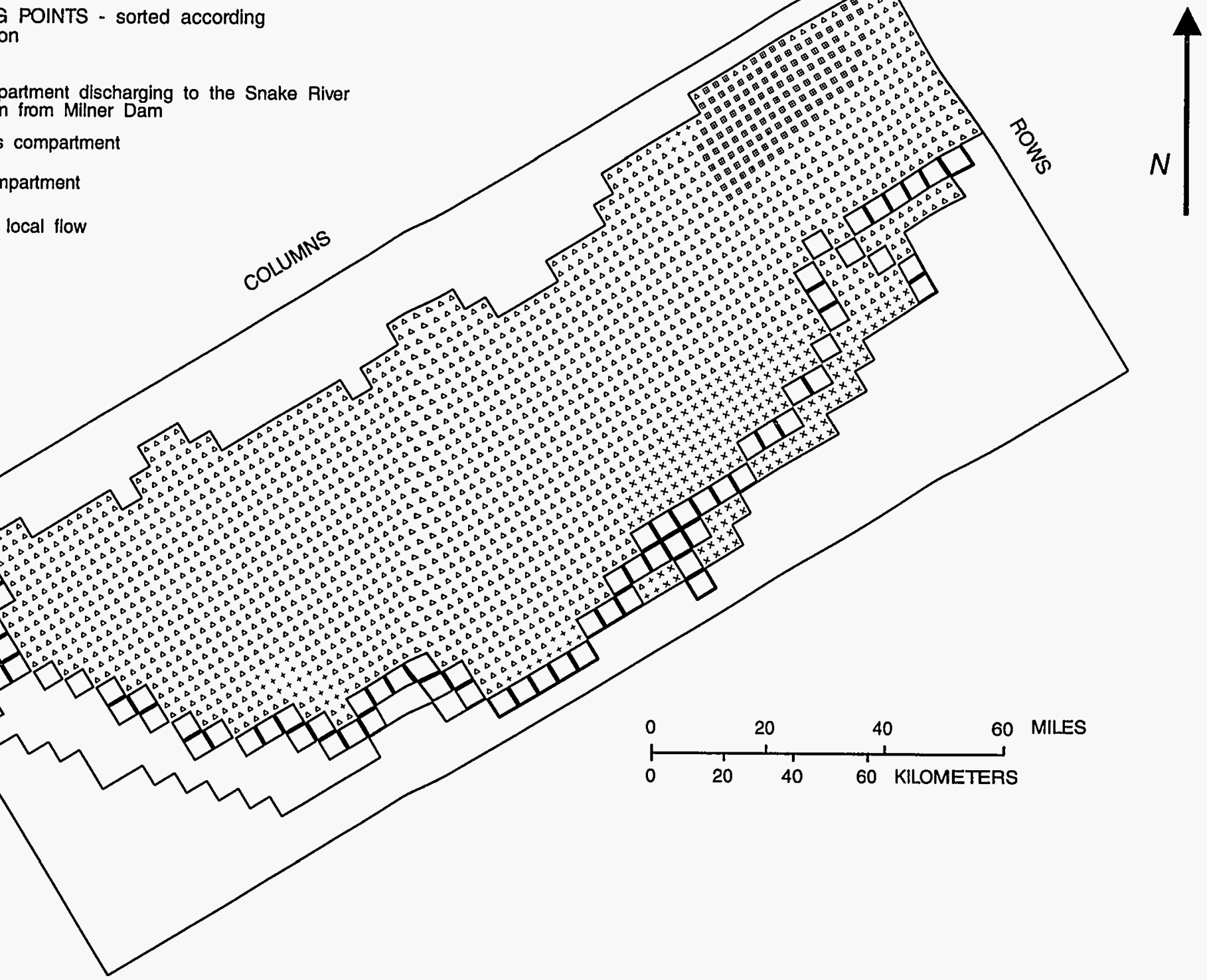

Figure 7. Sensitivity of interpretations regarding fate of flow to assumptions regarding influence of weak sinks. [Weak sinks greater than 0.6 of total inflow to a cell stop particle movement] 


\section{EXPLANATION}

-5,000 - SIMULATED POTENTOMETRIC CONTOUR -. Shows altitude of water table, 1980. Contour intervals 200 and 500 feet. Datum is sea level

PATHUNES FOR PARTICLES STARTING AT THE WATER TABLE (Sorted according to discharge location)

Regional compartment discharging to Snake River downstream from Milner Dam American Falls compartment discharging along the east side of the aquifer

Mud Lake compartment discharging near Mud Lake
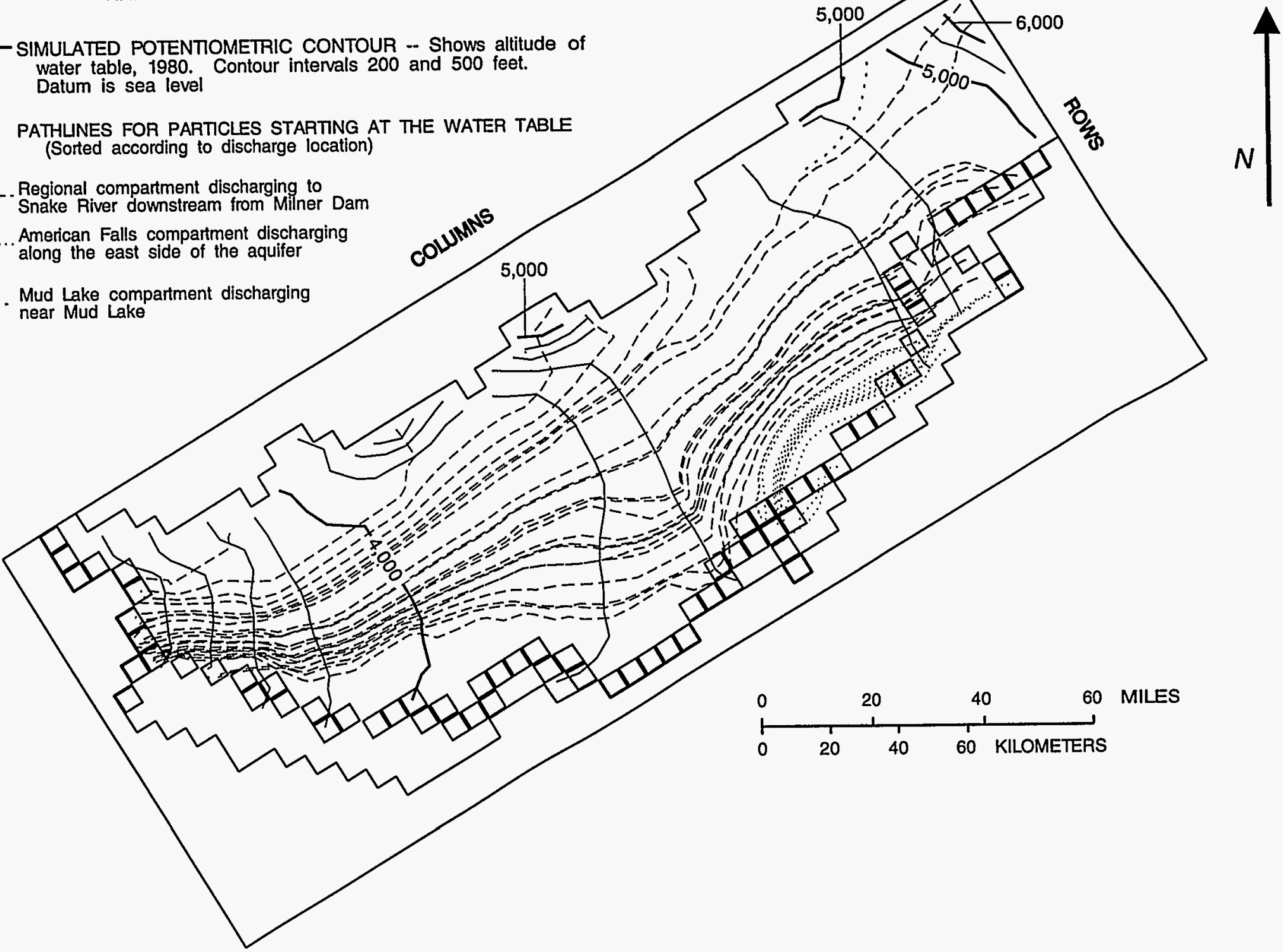

Figure 8. Selected pathlines for regional and intemediate flow and configuration of the simulated water table, eastem Snake River Plain regional aquifer system. [Pathlines are projected to the surface of the aquifer] 


\section{Traveltime}

The results of an analysis of traveltime for advective flow in the regional compartment are illustrated on figure 9. This simplistic representation of traveltime for flow in the aquifer was constructed using the existing conceptual and numerical models. The illustration was constructed by posting the starting points sorted by intervals of traveltime. The model was calibrated for average flow conditions for the period 1950-80, very nearly the time period for the calibration of traveltime: 1953-83 for tritium and 1953-91 for iodine-129. Inasmuch as flow conditions in the aquifer differ from the 1950-80 average because of changes in climate or land use, the interpretation of traveltime is more or less representative.

Traveltimes for advective flow from the water table to discharge points in the regional compartment ranged from 12 to 350 years for 80 percent of the particles. For discharge in the American Falls compartment, 80 percent of the particles had traveltimes between 7 and 60 years. For discharge in the Mud Lake compartment 80 percent of the particles had traveltimes between 25 and 100 years.

Traveltimes are sensitive to porosity and assumptions regarding the importance of the strength of internal sinks, which represent groundwater pumpage. The distribution of traveltimes for all particles starting near the water table is presented in cumulative distribution graphs (figs. 10 and 11).

Traveltime is a function of the product of thickness and porosity

$$
t \approx \frac{b n A}{Q},
$$

where $t$ is the traveltime, $b$ is the aquifer thickness, $n$ is the porosity, $A$ is the area, and $Q$ is the volumetric flow rate. Because thickness also is directly related to traveltime, the sensitivity to values of thickness will be similar to that of porosity. Traveltimes were sensitive to both the value of porosity and the ratio of porosity between the upper and lower parts of the aquifer. A decrease in porosity resulted in shorter traveltimes, but not a uniform decrease in traveltime because the porosity and thickness was different in each model layer. The distribution of traveltimes was not as sensitive to variation in thickness, especially the thickness of lower layers, because most flow was horizontal and occurred in the top two layers.

Assumptions regarding the importance of the strength of internal sinks may affect the calculation of the endpoints of pathlines for particles and therefore the traveltime. As more and more particles are stopped when they reach a cell with a stronger sink, the shift in the distribution of traveltimes indicates a decrease in traveltimes. The model is not uniformly sensitive to a change in the ratio that governs which cells have a weak sink strong enough to simulate capturing a part of regional flow. This nonuniformity is most likely a consequence of the areal distribution and rate of ground-water pumpage.

\section{LIMITATIONS OF MODEL}

The model developed for this study has limitations that must be understood if it is to be used effectively. These limitations concern the underlying assumptions of the particle-tracking package, the discretization of the aquifer system, and the assumptions regarding uncertainty in model parameters and boundary conditions. The limitations because of the underlying assumptions of the method are covered in Pollock (1989, p. 19).

\section{Discretization}

An important limitation of this model is the assumption of steady-state flow. The most recent trend in the flow system has been a decrease in recharge since 1987 because of an extended drought and changes in land use (Kjelstrom, 1992a). A decrease in flow through the system would result in traveltimes longer than those predicted for a greater flow.

Conceptualization of well discharge as internal sinks resulted in the creation of many weak sinks for the discretization of this model. Discretization resulted in some ambiguity near the Mud Lake intermediate-scale discharge area. The interpretation of the size of the flow system compartment might be underestimated because of the 
EXPLANATION

TRAVELTIME FOR PARTICLES ORIGINATING AT THE WATER TABLE

$\because \quad$ Less than 50 years

$x^{+} \quad 50$ to 100 years

" 100 to 200 years

$\because \quad 200$ to 300 years

* Greater than 300 years

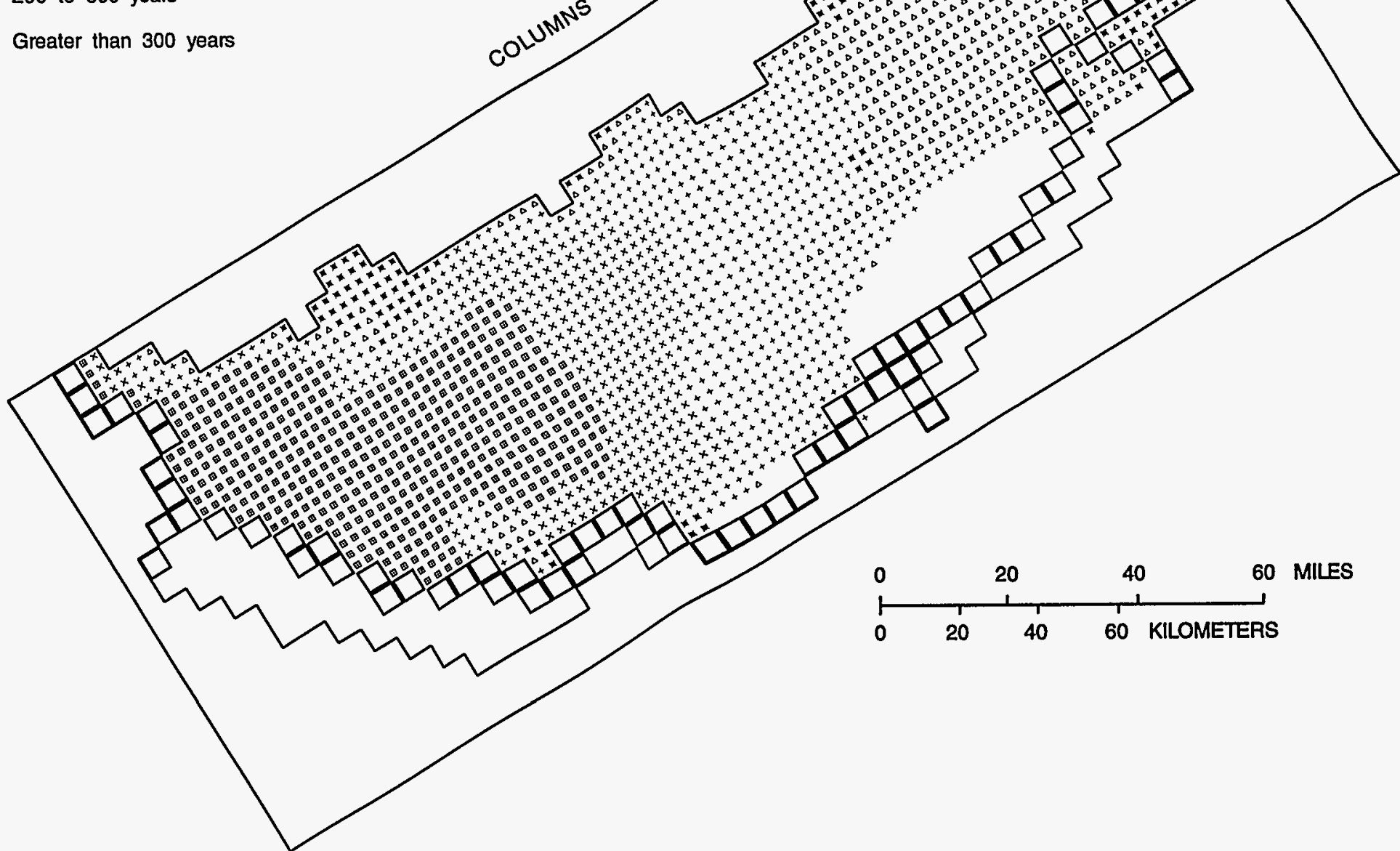

Figure 9. Traveltimes for simulated flow originating at the water table in the eastem Snake River Plain regional aquifer system and discharging to the Snake River downstream from Milner Dam. 


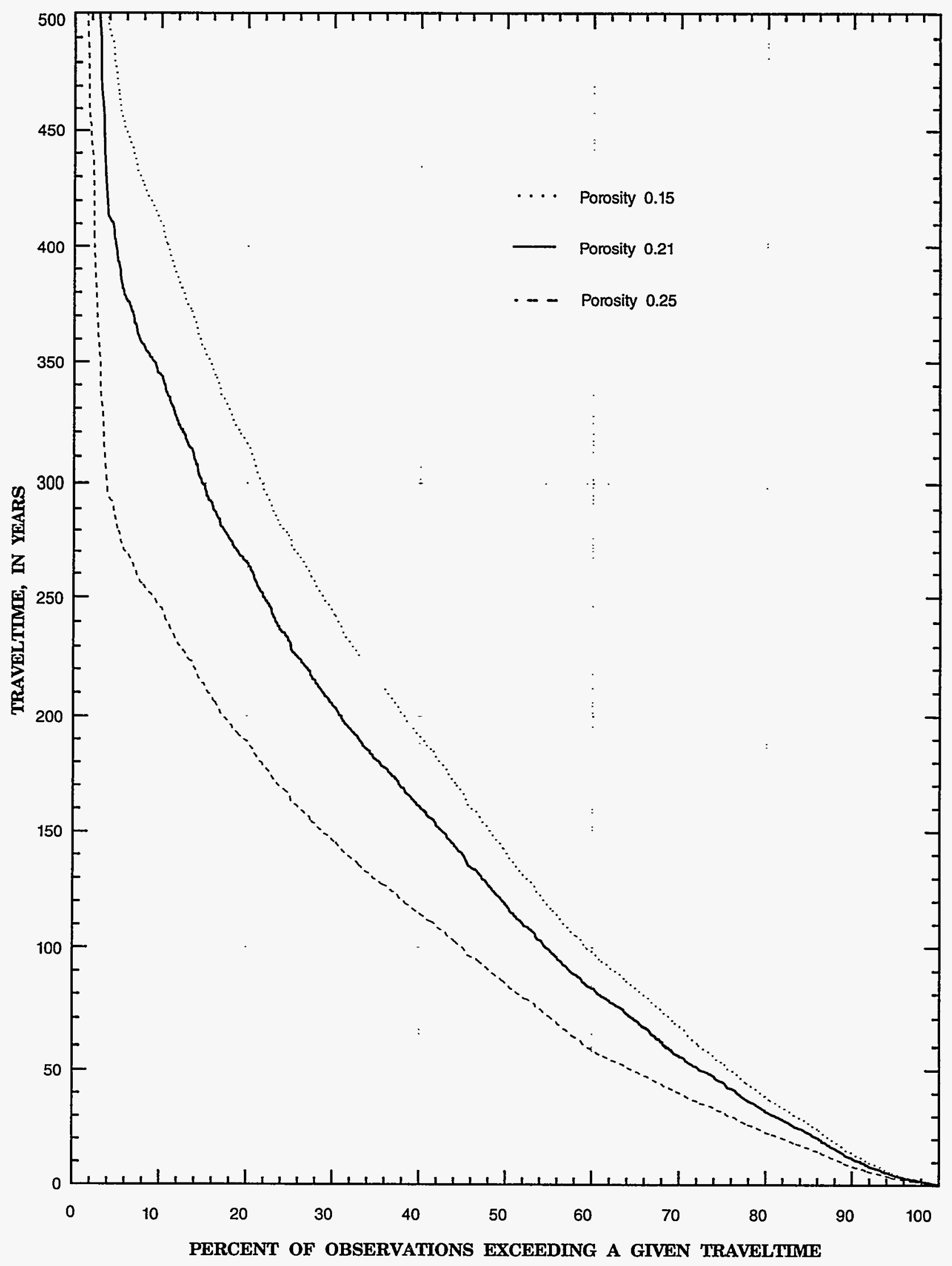

Figure 10. Sensitivity of simulated traveltime to uniform changes in porosity. 


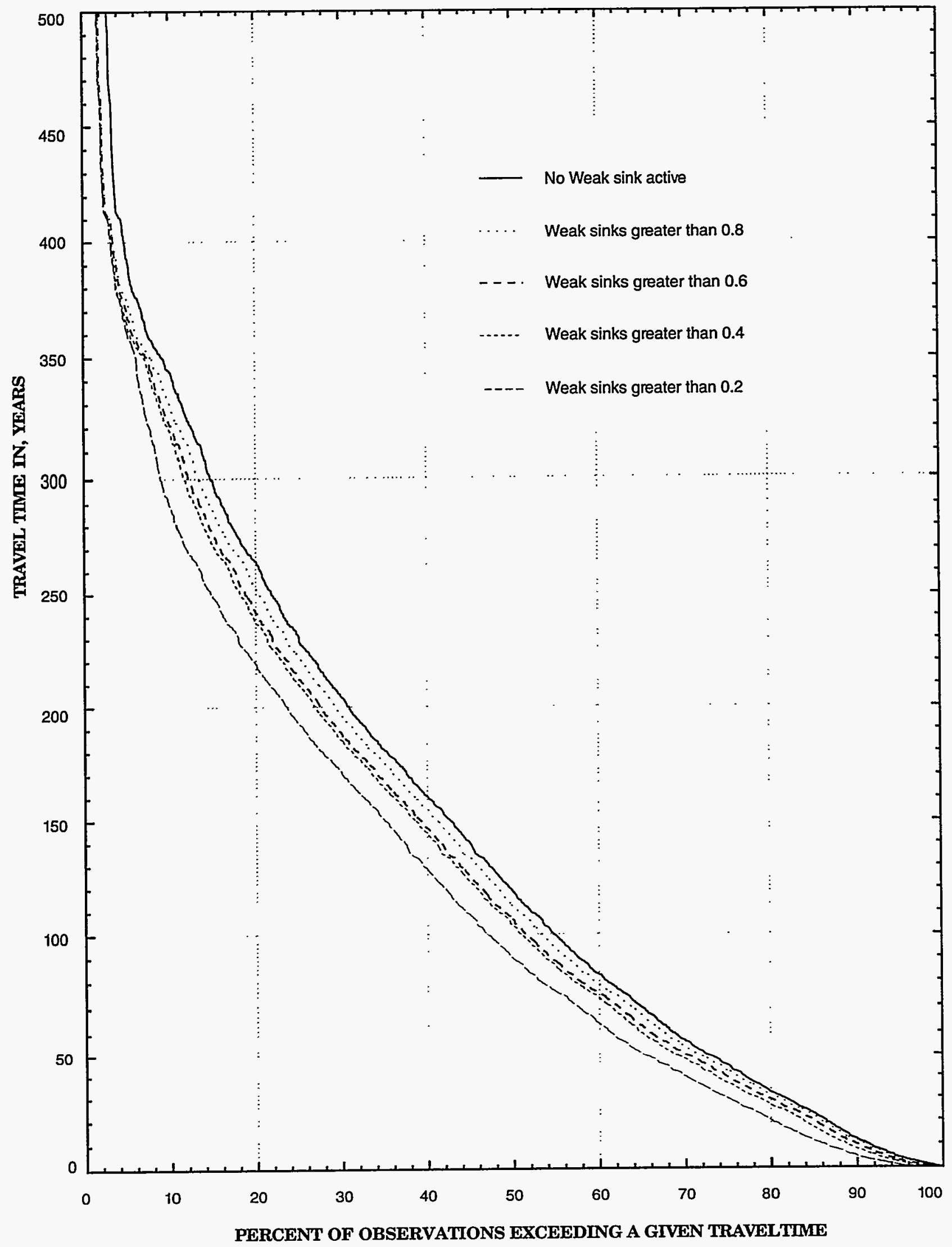

Figure 11. Sensitivity of simulated traveltime to influence of weak sinks. [Weak sinks stop particles when they are greater than a given proportion of total inflow to a model cell] 
assumption that discharge to wells is uniformly distributed throughout the cell. Because the interpretation of the model was limited to flow on a larger scale and did not consider individual wells or well fields, the interpretations were not seriously limited by the discretization of well discharge.

Interpretations made from this model also were limited by the discretization of the major discharge areas along the Snake River. Discharge to the Snake River is known and calibrated only for an entire reach length, a distance covering several model cells. Near discharge areas, pathlines are representative at a scale slightly coarser than the resolution of the grid.

\section{Assumptions}

The most important assumption of this study is the use of the existing flow model and the assumptions inherent in that model (Garabedian, 1992, p.31). The flow model is assumed to be the best existing description of the regional flow system. The flow model was most sensitive to changes in transmissivity and recharge, sensitive to riverbed or spring-outlet conductances near major discharge areas, and relatively insensitive to changes in boundary flux and ground-water pumpage (Garabedian, 1992, p. 59). The calibration of transmissivity is related to the distribution of head measurements of the aquifer; the calibration of recharge to the quality of the data used in the estimates of recharge. Garabedian (1992, p. 59, 63) suggests that improvement can be gained by better estimates of surface-water diversions, irrigation-return flow, streamflow, and groundwater pumpage. Most of these improvements are related to estimates of recharge from surface-water irrigation.

The model is most sensitive to the estimate of the largest inflow. Like most models, this flow model is not a unique approximation of the flow system. The results of this study are a representation of how, where, and how fast water moves in an idealized system approximated by the flow model.

The value for porosity of aquifer materials used for simulation in this study might not be transferable to other models with different scales, discretizations, and assumptions. The calibration of traveltime in this study is possibly a calibration of a parameter made up of the product of porosity, 0.21 , and thickness, $200 \mathrm{ft}$, of layer 1.

The calibration was based on the assumption that iodine- 129 is relatively conservative. Recent data for chlorine-36, which has a half-life of 301,000 years and a lower detection limit, indicate that iodine-129 is slightly attenuated (L.D. Cecil, U.S. Geological Survey, written commun., 1994). Preliminary results from the analysis of archived samples indicate that traveltimes to well USGS 11 may be a few years shorter for chlorine-36. The shorter travel time for chorine-36 would indicate that the aquifer porosity may be slightly less than the value of 0.21 used to calibrate the advective transport model (fig. 5).

\section{SUMMARY}

Quantitative estimates of ground-water flow directions and traveltimes for advective flow were developed for the regional aquifer system of the eastern Snake River Plain, Idaho. The work included: (1) descriptions of compartments in the aquifer that contain separate regional or intermediate flow systems, (2) descriptions of pathlines for flow originating at or near the water table, and (3) quantitative estimates of traveltimes for advective transport originating at or near the water table.

Two numerical models were necessary to simulate steady-state advective transport in the aquifer. An existing model simulates threedimensional steady-state flow, and an advective transport model developed in this study computes three-dimensional pathlines.

Advective transport in the aquifer was modeled using a particle-tracking postprocessing package developed for use with the USGS modular flow model. The particle tracking postprocessing program was used to compute pathlines on the basis of output from flow model simulations. No consideration was given to the processes of dispersion or to the physical, chemical, and biological transformation of solutes. The model of flow uses 1980 conditions to approximate average annual conditions for 1950-80. 
The advective transport model required additional information about the nature of flow across model boundaries, aquifer thickness, and porosity. Aquifer thickness was not an input variable for the flow model but was documented in the descriptions of an intermediate step in the creation of transmissivity arrays. In the advective transport model, all flux was distributed evenly across cell faces or as an internal sink. Some data exist that serve as a guide for reasonable input values for porosity. Porosity of two types of basalt strata has been determined for more than 1,500 individual cores from test holes, wells, and outcrops near the south side of the Idaho National Engineering Laboratory. The central 80 percent of samples had porosities of 0.08 to 0.25 , the central 50 percent of samples, 0.11 to 0.21 .

The calibration of this model involved choosing a value for the least known or defined parameter, porosity, which yielded the best solution. Two radiologic contaminants, iodine-129 and tritium, both introduced to the flow system about 40 years ago, were available to act as relatively conservative tracers. The traveltime for iodine- 129 was considered to be more useful for comparison with predicted traveltimes, because of a lower analytical detection limit, longer half-life, and longer flow path. The absolute value of the difference between simulated and estimated traveltimes for the radiologic contaminants was chosen as the calibration criterion. To the nearest two significant figures the calibration value for porosity was 0.21 , the value that allowed the model to simulate the traveltime for iodine-129. Values of 0.15 and 0.25 were chosen as representative of the probable range of porosity and were used for sensitivity analysis. This range is similar to the range of observed values and is only slightly higher than the range of values used for other studies or suggested by other studies.

The results of simulations of particle travel can be analyzed to develop or extend knowledge of the compartmentalization of the aquifer, flow paths in the aquifer, and traveltime for flow in the aquifer. Most flow in the aquifer follows regional paths that discharge to the Snake River downstream from Milner Dam. Intermediate-scale compartments exist along the southeast side of the aquifer and near Mud Lake.
The American Falls compartment along the southeast side of the aquifer discharges to the Snake River near American Falls Reservoir and covers an area of nearly $1,000 \mathrm{mi}^{2}$. The recharge from intensive surface-water irrigation along the southeast side of the aquifer results in a concentration of ground-water flow. The flow system within the compartment is apparently fairly stable because the mean annual ground-water discharge to this reach of the Snake River has been consistent since 1912.

The Mud Lake compartment covers an area of $300 \mathrm{mi}^{2}$. The stability or size of the flow system within this compartment is uncertain. The existence of Mud Lake before irrigation development may be evidence of a stable discharge area reflecting intermediate-scale flow, but the changes in size since 1908 indicate that the size of the flow system is in a state of change.

To test the sensitivity of model results to assumptions regarding weak sinks, endpoints of flow and traveltimes were calculated for scenarios where weak sinks of four different strengths were allowed to stop particles. Interpretations regarding the compartments were sensitive to assumptions regarding the importance of the strength of internal sinks. The effects of allowing weak sinks to stop particles were that the size of the Mud Lake compartment is larger and more miscellaneous local flow is indicated. At the end of the flow system, the pathlines converge at the discharge area. Because the pathlines are an approximation of most flow, the density is greatest near the cells representing the river reaches with the greatest gain from the aquifer.

Traveltimes for advective flow from the water table to regional discharge areas in the regional compartment ranged from 12 to 350 years for 80 percent of the particles. For discharge in the American Falls compartment, 80 percent of the particles had traveltimes between 7 and 60 years. For discharge in the Mud Lake compartment, 80 percent of the particles had traveltimes between 25 and 100 years.

Traveltimes are sensitive to porosity and assumptions regarding the importance of the strength of internal sinks that represent ground- 
water pumpage. A decrease in porosity resulted in shorter traveltimes but not a uniform decrease in traveltime because the porosity and thickness was different in each model layer. Most flow was horizontal and occurred in the top two layers that simulate the top $500 \mathrm{ft}$ of the aquifer. Assumptions regarding the importance of the strength of internal sinks may affect the calculation of the endpoints of pathlines for particles and therefore the traveltime. As more and more particles are stopped when they reach a cell with a stronger weak sink, the shift in the distribution of traveltimes indicates a decrease in traveltimes. The model is not uniformly sensitive to a change in the ratio that governs which cells have a weak sink strong enough to simulate capturing a part of regional flow. This nonuniformity is most likely a consequence of the areal distribution and rate of ground-water pumpage.

In addition to the limitations because of the underlying assumptions of the method, there are limitations because of discretization effects, uncertainty in input data, and other assumptions. An important limitation of the model is the assumption of steady-state flow. The most recent trend in the flow system has been a decrease in recharge since 1987, because of an extended drought and changes in land use. A decrease in flow through the system would result in traveltimes longer than those predicted for a greater flow. The conceptualization of well discharge as internal sinks resulted in the creation of many weak sinks for the discretization of this model. Because the interpretation of the model was limited to flow on a larger scale, and did not consider individual wells or well fields, the interpretations were not seriously limited by the discretization of well discharge.

The interpretations made from this model also were limited by the discretization of the major discharge areas. Discharge to the Snake River is known and calibrated only for an entire reach length, a distance covering several model cells. Near discharge areas, pathlines might not be representative at the resolution of the grid. The most important assumption of this study is the use of the existing flow model and the assumptions inherent in that model. The flow model is assumed to be the best existing description of the regional flow system. The flow model was most sensitive to changes in transmissivity and recharge, sensitive to riverbed or spring-outlet conductances near major discharge areas, and relatively insensitive to changes in boundary flux and ground-water pumpage. Most improvement in the estimates of ground-water flow directions and traveltimes for advective flow could be gained by better estimates of recharge from surface-water irrigation.

\section{REFERENCES}

Barraclough, J.T., Teasdale, W.E., Robertson, J.B., and Jensen, R.G., 1967, Hydrology of the National Reactor Testing Station, Idaho, 1966: U.S. Geological Survey Open-File Report (IDO-22049), $95 \mathrm{p}$.

Bishop, C.W., 1991, Hydraulic properties of vesicular basalt: Tucson, University of Arizona, unpublished M.S. thesis, $115 \mathrm{p}$.

Doherty, D.J., McBroome, L.A., and Kuntz, M.A, 1979, Preliminary geological interpretation and lithologic log of the exploratory geothermal test well (INEL-1), Idaho National Engineering Laboratory, eastern Snake River Plain, Idaho: U.S. Geological Survey Open-File Report 79-1248, $95 \mathrm{p}$.

Freeze, R.A., and Cherry, J.A., 1979, Groundwater: Englewood Cliffs, N.J., Prentice-Hall, 604 p.

Garabedian, S.P., 1992, Hydrology and digital simulation of the regional aquifer system, eastern Snake River Plain, Idaho: U.S. Geological Survey Professional Paper 1408-F, 102 p., 10 pls.

Heath, R.C., 1984, Ground-water regions of the United States: U.S. Geological Survey Water-Supply Paper 2242, 78 p.

Kjelstrom, L.C., 1992a, Assessment of spring discharge to the Snake River, Milner Dam to King Hill, Idaho: U.S. Geological Survey Open-File Report 92-147 (Water Fact Sheet), [2] p.

-----1992b, Streamflow gains and losses in the Snake River and ground-water budgets for the Snake River Plain, Idaho and eastern Oregon: U.S. Geological Survey Open-File Report 90-172, 71 p.

Knutson, C.F., McCormick, K.A., Crocker, J.C., Glenn, M.A., and Fishel, M.L., 1992, 3D RWMC vadose zone modeling (including FY-89 to FY-90 basalt characterization results): EG\&G Idaho, Inc., Report EGG-ERD-10246 [variously paged]. 
Knutson, C.F., McCormick, K.A., Smith, R.P., Hackett, W.R., O'Brien, J.P., and Crocker, J.C., 1990, FY-89 RWMC vadose zone basalt characterization: EG\&G Idaho, Inc., Report EGG-WM-8949 [variously paged].

Lewis, B.D., and Goldstein, F.J., 1982, Evaluation of a predictive ground-water solute-transport model at the Idaho National Engineering Laboratory, Idaho: U.S. Geological Survey Water-Resources Investigations Report 82-25 (IDO-22062), 71 p.

Lindholm, G.F., 1993, Summary of the Snake River Plain regional aquifer-system analysis in Idaho and eastern Oregon: U.S. Geological Survey Open-File Report 91-98, 62 p., 1 pl.

McDonald, M.G., and Harbaugh, A.W., 1988, A modular three-dimensional finite-difference ground-water flow model: U.S. Geological Survey Techniques of Water-Resources Investigations, book 6, chap. A1, 586 p.

Mann, L.J., 1986, Hydraulic properties of rock units and chemical quality of water for INEL-1—a 10,365foot deep test hole drilled at the Idaho National Engineering Laboratory, Idaho: U.S. Geological Survey Water-Resources Investigations Report 864020 (IDO-22070), 23 p.

Mann, L.J., and Beasley, T.M., 1994, Iodine-129 in the Snake River Plain aquifer at and near the Idaho National Engineering Laboratory, Idaho, 1990-91: U.S. Geological Survey Water-Resources Investigations Report 94-4053 (IDO-22115), 27 p.

Mann, L.J., and Cecil, L.D., 1990, Tritium in ground water at the Idaho National Engineering Laboratory, Idaho: U.S. Geological Survey WaterResources Investigations Report 90-4090 (DOE/ID-22090), $35 \mathrm{p}$.

Meinzer, O.E., 1927, Large springs in the United States: U.S. Geological Survey Water-Supply Paper 557, $93 \mathrm{p}$.

Nace, R.L., 1958, Hydrology of the Snake River basalt: Washington Academy of Science Journal, v. 48, no. 4, p. 136-138.

Newton, G.D., 1985, Computer programs for common map projections: U.S. Geological Survey Bulletin $1642,33 \mathrm{p}$.

Pollock, D.W., 1989, Documentation of computer programs to compute and display pathlines using results from the U.S. Geological Survey modular three-dimensional finite-difference ground-water flow model: U.S. Geological Survey Open-File Report 89-381, 188 p.
Robertson, J.B., 1969, Behavior of Xenon-133 gas after injection underground: Molecular diffusion, materials balance, and barometric pressure effects: U.S. Geological Survey Open-File Report (IDO-22051), $37 \mathrm{p}$.

Robertson, J.B., 1974, Digital modeling of radioactive and chemical waste transport in the Snake River Plain aquifer at the National Reactor Testing Station, Idaho:U.S. Geological Survey Open-File Report (IDO-22054), $41 \mathrm{p}$.

Robertson, J.B., 1977, Numerical modeling of subsurface radioactive solute transport from wasteseepage ponds at the Idaho National Engineering Laboratory: U.S. Geological Survey Open-File Report 76-717 (IDO-22057), 68 p.

Robertson, J.B., Schoen, Robert, and Barraclough, J.T., 1974, The influence of liquid waste disposal on the geochemistry of water at the National Reactor Testing Station, Idaho: U.S. Geological Survey Open-File Report (IDO-22053), 231 p.

Spinazola, J.M., 1994, Geohydrology and simulation of flow and water levels in the aquifer system in the Mud Lake area of the eastern Snake River Plain, eastern Idaho: U.S. Geological Survey WaterResources Investigations Report 93-4227, 78 p.

Stearns, H.T., Bryan, L.L., and Crandall, Lynn, 1939, Geology and water resources of the Mud Lake region, Idaho: U.S. Geological Survey WaterSupply Paper 818, 125 p., 13 pls.

Whitehead, R.L., 1992, Geohydrologic framework of the Snake River Plain regional aquifer system: U.S. Geological Survey Professional Paper 1408-B, 32 p., 6 pls. 